\title{
Kadın Astların Perspektifinden Kadın Yöneticiler: Hiyerarşik İlişkiler Bağlamında Nitel Bir Araştırma (Women Managers from the Perspective of Women Subordinates: A Qualitative Research in the Context of Hierarchical Relationships)
}

\section{Ebru TOLAY iD a}

a Dokuz Eylül Üniversitesi, İktisadi Ve İdari Bilimler Fakültesi, İşletme Bölümü, İzmir, Türkiye. ebru.tolay@deu.edu.tr

\begin{tabular}{|c|c|}
\hline MAKALE BİLGİSİ & ÖZET \\
\hline Anahtar Kelimeler: & \multirow{6}{*}{$\begin{array}{l}\text { Amaç - Literatürde, kadın ve erkek çalışanların kadın yöneticilerle çalışmayı genellikle tercih etmedikleri } \\
\text { ifade edilmekte ve bu durumun nedenleri hem toplumsal cinsiyet rollerine ilişkin kalıp yargılara hem de } \\
\text { Sosyal Kimlik Teorisi perspektifiyle Kraliçe Arı Sendromu gibi olgulara dayandırılmaktadır. Bu } \\
\text { çalışmanın temel amacı, kadın çalışanların kadın yöneticileri hakkındaki algılamalarını ve tutumlarını } \\
\text { araştırmak ve iş yaşamında kadınlar arasındaki hiyerarşik ilişkileri mevcut yaklaşımlar ışığında } \\
\text { tartışmaktır. }\end{array}$} \\
\hline Kadın Yöneticiler & \\
\hline Kadın Calısanlar & \\
\hline Kadin Çälşaniar & \\
\hline Cinsiyetçi Kalıp Yargılar & \\
\hline raliçe Arı Sendromu & \\
\hline
\end{tabular}

Gönderilme Tarihi 3 Şubat 2020

Revizyon Tarihi 30 Haziran 2020

Kabul Tarihi 10 Temmuz 2020

Makale Kategorisi: Araştırma Makalesi

Yöntem - Tümevarım yaklaşımı ve fenomenolojik araştırma deseni ile nitel bir araştırma tasarlanarak 20 farklı sektörden 40 kadın çalışana ulaşılmıştır. Elde edilen veriler MAXQDA 2020 Nitel Veri Analizi Programı aracılığı ile İçerik Analizine tabi tutulmuştur.

Bulgular - Araştırmanın en önemli sonuçlardan biri, katılımcıların yüzde 38'inin erkek yönetici ile çalışmayı tercih ederken yüzde 18'inin kadın yönetici ile çalışmayı tercih etmesidir. Katılımcıların yüzde 13'ü ise tercihlerini, cinsiyet faktörünün değil, yöneticinin karakterinin ve yönetsel yetkinliğinin belirleyeceğini dile getirmişlerdir. Ayrıca araştırmaya katılanların yüzde 45'i kadın yönetici ile çalışmanın "güzel, rahatlatıcı ve güven verici bir duygu" olduğunu belirtirken yüzde 48'i "kötü, rahatsız ve tedirgin edici bir duygu" olduğunu ifade etmiştir. Katılımcıların yüzde 78'inin toplam $67 \mathrm{kez}$ değindiği önemli bir konu, "kadın" ve "anne" olmaları nedeniyle kadın yöneticiler tarafından daha iyi anlaşıldıklarını hissetmeleridir. Diğer taraftan, profesyonel bir iş ilişkisinde korunması gereken resmiyetin, kadın ast ve üstler arasında korunamaması ve kimi zaman sınırların aşılması, bir dezavantaj olarak sıkça dile getirilmiştir.

Tartışma - Araştırma sonuçları, kadın çalışanların erkek yöneticilerle çalışmayı tercih etme eğiliminin, literatüre paralel olarak devam ettiğini göstermiştir. Bununla birlikte, katılımcıların bu tercihinde kendi olumsuz deneyimlerinin belirleyici olduğu ve kadın yöneticileri genellikle cinsiyetten bağımsız faktörlerle değerlendirmeye çalıştıkları saptanmıştır.

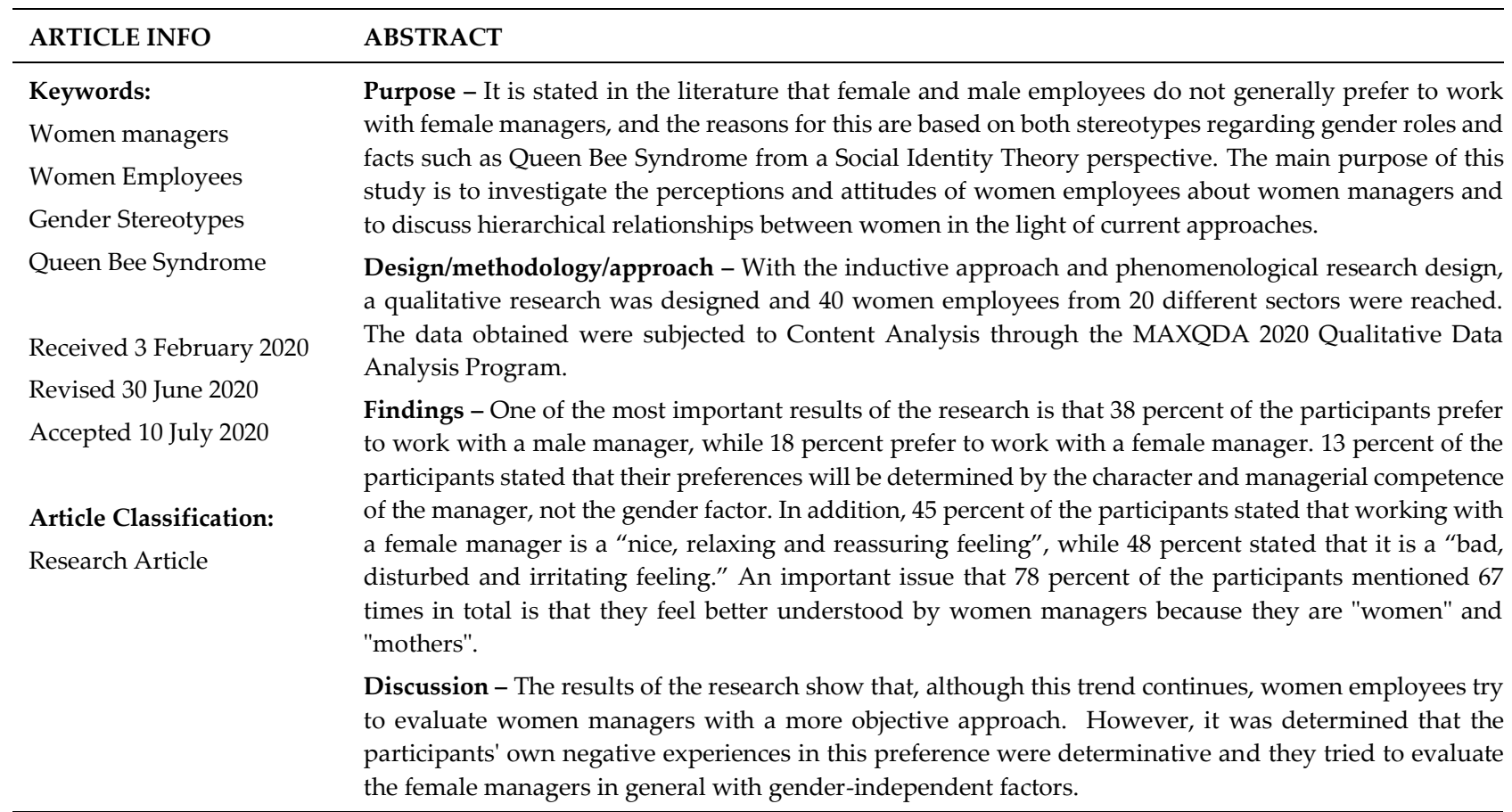

\section{Önerilen Atıf/ Suggested Citation}

Tolay, E. (2020). Kadın Astların Perspektifinden Kadın Yöneticiler: Hiyerarşik İlişkiler Bağlamında Nitel Bir Araştırma, İşletme

Araştırmaları Dergisi, 12 (3), 2276-2296. 


\section{GİRISS}

Kadınların iş yaşamındaki konumları, uzun yıllardan beri çeşitli açılardan incelenmektedir. Kadınların işgücüne katılma oranları, üst yönetim kademelerinde temsil edilme oranlarındaki yavaş artış, kariyer gelişmelerini etkileyen ayırımcı ve önyargılı davranış ve uygulamalar gibi konular temel başlıklar olarak öne çıkmaktadır (Örneğin Ataay, 1998; Aycan, 2004; Negiz ve Yemen, 2011; Schein, 2007; Sertkaya vd., 2013; Uçan, 2012; Ustabaş ve Afacan Findıkl1, 2017; Kurt Yılmaz, 2019). Örgütlerde özellikle üst düzey yönetim pozisyonları için kadınlara konulan keyfi, görünmeyen ancak hissedilen engelleri ifade eden Cam Tavan (Glass Ceiling) olgusu ile ilgili geniş bir literatür bulunmakta (örneğin Kanter, 1993; Jackson ve O'Callaghan, 2009; Karaca, 2007; Akbaş ve Korkmaz, 2017; Er ve Adıgüzel, 2015) ve bu duruma yol açan faktörler derinlemesine irdelenmektedir.

Literatürde kadın çalışanların iş yaşamındaki dezavantajlı konumları ve üst yönetim kademelerinde yer almalarını engelleyen faktörler, genellikle toplum tarafından bireylere atfedilen cinsiyet rollerine dayandırılmaktadır. Kadınların ve erkeklerin cinsiyetlerine özgü rol davranışlarının sosyal sistemler içerisinde öğrenme süreciyle kuşaktan kuşağa aktarıldığını vurgulayan Sosyal Öğrenme Kuramı çerçevesinde, çocukluktan itibaren öğrenilen bu rollerin kadını ve erkeği şekillendirdiği ifade edilmektedir.

İş yaşamında kadın ve erkek çalışanlara atfedilen ve onlardan beklenen rollerin farklılaşmasını açıklamada faydalı bir bakış açısı sunan bu yaklaşımın yanı sıra literatürde, diğer bireyleri tanımlamada kullanılan basitleştirilmiş kategorileri ifade eden stereotip ya da kalıp yargı kavramı üzerinde de sıklıkla durulmaktadır (Alemie, 2011; Duehr ve Bono, 2006; Eagly ve Johnson, 1990; Gmür, 2006; Schein, 2007; Stoker vd.,2012; Willemsen, 2002). Bu bağlamda, kadınların hak ve rolleri konusunda zaman içerisinde gelişmeler kaydedilse de kadınların erkeklerden farklı olduğu ve bu nedenle etkin bir yönetimin gereklerini yerine getiremeyecekleri görüşü, pek çok toplumda yaygın bir cinsiyetçi kalıp yargı olarak varlı̆̆ını devam ettirmektedir. Literatürde kadınların davranışları ve çalışma alışkanlıkları hakkındaki bu cinsiyetçi rol kalıplarının, kadınların ilerlemelerinde gerçek ve olumsuz bir etkisi olduğu ifade edilmektedir. Örneğin, kadınların kariyerlerine erkekler kadar bağlı olmadıkları, uzun saatler çalışmak istemedikleri, çok duygusal oldukları, karar verme kapasitelerinin düşük olduğu, sayısal yeteneklerinin olmadığı gibi "olumsuz"; sıcak ve şefkatli oldukları, insanlarla iyi geçindikleri, yaratıcı, sadık ve iyi bir takım oyuncusu oldukları gibi "olumlu" kalıp yargılar (Ataay, 1998: 245), çalışma yaşamında kadınların yapacakları işleri, ulaşabilecekleri yönetsel kademeleri ve yönetici konumuna geldiklerinde ise onlardan beklenen rolleri belirlemede etkili olmayı sürdürmektedir.

Özen (1998: 219), kadın ve erkek yöneticilerin yönetim tarzı açısından ne derece farklılaştıklarının ve mevcut farklılıkların ne derece toplumsal cinsiyete veya durumsal değişkenlere bağımlı olduğunun Türkiye'de kapsamlı olarak incelenmediğini ifade etmiş ve ilgili yazının, daha çok kadının toplumsal, ekonomik ve siyasal yaşamdaki rolü ve çalışma yaşamında kadın işgücünün genellikle niceliksel özellikleri üzerinde yoğunlaştığını ifade etmiştir. Günümüze gelindiğinde gerek yabancı gerekse yerli yazında bu eğilimin devam ettiğini söylemek mümkündür. Kadın ve erkek yöneticiler arasındaki farklılıkları inceleyen çeşitli araştırmalar bulunmakla birlikte (American Psychological Association, 2006; Berkman, 2005; Boulgarides, 1984; Mukhtar, 2002; Powell, 1990; Statham, 1987; Sundaresan, 2010), ast konumundaki kadınların üstleri konumundaki kadın yöneticileri değerlendirdiği araştırmalar sınırlıdır (Hurst vd., 2018a, 2018b; İmamoğlu Akman ve Akman, 2016). Mevcut çalışmalar incelendiğinde ise bunların, konuyu genellikle kadın yöneticilerin kadın astlarına uyguladığı mobbing boyutu ile ele aldıkları (Cevher ve Öztürk, 2015; Karakuş, 2014) ve bu durumun nedenlerini de Kraliçe Arı fenomenine ve Sosyal Kimlik Teorisine dayandırdıkları dikkat çekmektedir (Bickford, 2011; Derks vd., 2011a, 2011b, 2016; Er ve Adıgüzel, 2015).

Uzun yıllardan beri tartışılan bu olgular çerçevesinde, bu çalışmanın temel amacı, kadın çalışanların gözünden kadın yöneticilerin tutumlarını ve yöneticilik tarzlarını araştırmak; kadın yöneticilere karşı önyargılı tutumların bulunup bulunmadığını incelemek ve böylece günümüz iş yaşamında ast-üst konumundaki kadınlar arasındaki iş yeri ilişkilerine ışık tutmaktır. Bu amacı gerçekleştirmek için 20 sektörden 40 kadın çalışan ile nitel bir araştırma gerçekleştirilmiştir. Katılımcılardan, bir kadın olarak kadın yönetici ile çalışmanın nasıl bir duygu olduğunu değerlendirmeleri, erkek ve kadın yöneticiler arasında farklar olup olmadığı, fark olduğunu düşünüyorlarsa bunların nedenlerinin neler olduğu, kadın yöneticilerle birlikte çalışmanın avantaj ve dezavantajlarının neler olduğu sorularına yanıt vermeleri istenmiştir. Kadın çalışanların 
algılamalarının, onların kadın ya da erkek yönetici ile çalışma tercihlerine ne şekilde yansıdığı da irdelenmiştir.

Çalışmanın, günümüz Türkiye'sinde farklı sektörlerden ve farklı mesleklerden kadınların, kadın yöneticiler hakkındaki algılamalarını açığa çıkarması ve geçmişten günümüze, bakış açısında değişim olup olmadığını tartışması bakımından faydalı olacağı düşünülmektedir. Zira, literatürde kadın yöneticilerin kadın çalışanlarına yönelik mobbing davranışlarını inceleyen araştırmalar bulunmakla birlikte konuyu olumlu ve olumsuz yönleri ile birlikte ele alan ve nitel araştırma verileri ile bunları destekleyen çalışmaların sayısının yeterli olmadığı düşünülmektedir. Böyle bir araştırmanın yapılmasının ve sonuçlarının gerek günümüz iş yaşamı açısından gerekse yönetim, cinsiyet rolleri, kadın araştırmaları ile ilgili literatürler açısından tartışılmasının bu alanlara katkı sağlaması umulmaktadır.

\section{KURAMSAL ÇERÇEVE}

Kadın yöneticiler ile ilgili literatürdeki çalışmaları, "yönetimde kadın-erkek farklılaşması" ve "yönetimde kadın-erkek benzeşmesi" gibi iki temel başlık altında incelemenin, konunun farklı ve çok yönlü doğasını anlamada yararlı bir yaklaşım olacağı düşünülmektedir.

\subsection{Yönetimde Kadın - Erkek Farklılaşması}

Kadın yöneticiler ile erkek yöneticiler arasında farklılık olup olmadığını; varsa bu farklılıklara yol açan faktörleri araştıran çeşitli çalışmalarda (örneğin, Alemie, 211; Ataay, 1998; Balgiu, 2012; Boulgarides, 1984; Burke ve Collins, 2001; Eagly ve Johannesen-Schmidt, 2001; Mukhtar, 2002; Özen, 1998, Powell, 1990), söz konusu farklılıkların genellikle toplum tarafından bireylere atfedilen cinsiyet rollerine dayandığ 1 ve toplumsallaşma süreci ile bu rollerin zaman içerisinde toplumun üyeleri tarafından benimsendiği ifade edilmektedir.

Sosyal Öğrenme Kuramı, kadınların ve erkeklerin cinsiyetlerine özgü rol davranışlarının sosyal sistemler içerisinde öğrenme süreciyle kuşaktan kuşağa aktarıldığını vurgulamaktadır. Çocukluktan itibaren öğrenilen bu roller kadını ve erkeği şekillendirmekte, hassas ve duygusal özellikleri nedeniyle kadınlar ev işleri, çocuklar ve aile ile ilgili sorumluluklar üstlenirken; liderlik ve baskınlık özellikleriyle erkekler ise evin geçimini sağlama görevine uygun davranmaktadır. Belirlenen cinsiyet rollerine dayanan ayırımlar çalışma hayatı içerisinde kadın ve erkeğin farklı konumlandırılmasına, yönetim işinin de cinsiyetçi bir bakış açısı ile değerlendirilmesine neden olmuştur (Kızıldağ, 2018: 49). Bu bağlamda, gerek astlar, üstler ve meslektaşların kadın yöneticilere ilişkin algılamaları gerekse kadın yöneticilerin kendi rollerine ilişkin algılamaları onların iş yaşamındaki tutum ve davranışlarına yansımaktadır. Toplumlar arasında bazı farklılıklar olmakla birlikte genellikle kadınlardan duygusal, şefkatli, yardımsever, duyarlı ve fedakâr olmaları beklenirken, erkeklerden rekabetçi, başarıya odaklı, bağımsız, akılcı, pragmatist ve egemen olmaları beklenmektedir. Birbirine karşıt bu roller, zaman içinde, kadın ve erkek tarafından benimsenmekte ve sonuç olarak toplum tarafından kendilerine atfedilen bu rollere uygun kişilik özellikleri sergilemektedirler (Özen, 1998: 217-218).

\subsection{Yönetimde Kadın - Erkek Benzeşmesi}

Kadın yöneticiler ile ilgili literatürün bir diğer temel konusunu, yönetimde kadın-erkek benzeşmesi oluşturmaktadır. Bu olgu, tarihi olarak erkekler tarafından tasarımlanan ve yönetilen örgütlerin üst düzeylerinde marjinal bir konuma sahip olan kadın yöneticilerin, mevcut örgütsel ve yönetsel normlara uyum sağlama, hiyerarşide üst basamaklara ulaşma gibi güdülerle erkeklere benzer davranışlar gösterdiklerini ifade etmektedir. Bir başka deyişle, erkeklerin egemen olduğu bir sistemde, kadınların üst düzeylere tırmanabilmek ve o düzeylerde başarılı bir biçimde kalabilmek için kimi zaman eril eğilimler edinmeleri ve eril bir yönetim tarzı benimsemeleri söz konusu olabilmektedir. Yönetim alanında kadın-erkek benzeşmesi, kadın ve erkeğin benzer koşullarda çalışmalarına bağlanabileceği gibi, kadınların özellikle yönetsel düzeydeki azınlık konumuna da bağlanabilir (Özen, 1998: 219,221).

Kadınların dayanışma içine girerek ve birlikte hareket ederek yönetsel pozisyonlardaki dezavantajlı konumlarını iyileştirmeleri, yönetsel pozisyonlar için eksikliklerini gidermeleri, cinsiyete dayalı önyargılardan kaynaklanan engelleri aşmaları beklenirken, yönetimde kadın erkek benzeşmesinin bir sonucu olarak kimi zaman hemcinsleri olan kadın yöneticiler tarafından da engellerle karşılaştıkları görülmektedir (Kızıldağ, 2018: 59). "Kraliçe Arı Sendromu (Queen Bee Syndrome)" olarak nitelendirilen bu olgu, eril kültüre uyum sağlayarak ve kendilerini diğer kadınlardan uzaklaştırarak erkek egemen iş ortamlarında bireysel 
başarı elde eden kadınlara atfedilmektedir. Bu fenomen üzerine yapılan araştırmalar, kadınların bunu eril davranışları daha fazla sergileyerek, kendilerini diğer kadınlardan fiziksel ve psikolojik olarak uzaklaştırarak ve mevcut cinsiyet hiyerarşisini onaylayıp meşrulaştırarak yaptıklarını ortaya koymuştur (Derks vd., 2016: 457). Kraliçe arı fenomeninin, bu yönüyle, iş yaşamında yönetim kademelerindeki kadınlar ile ast konumundaki kadınlar arasındaki hiyerarşik ilişkileri anlamada önemli bir bakış açısı sunduğu söylenebilir.

Literatürde Kraliçe Arı fenomenine son yıllarda ağırlık verildiği ve bu olgunun altında yatan nedenlerin derinlemesine araştırıldığı ve bu bağlamda yapılan açıklamaların Sosyal Kimlik Teorisine dayandırıldığı görülmektedir (örneğin Baykal, 2018; Bickford, 2011; Derks vd., 2011a, 2011b, 2016; Er ve Adıgüzel, 2015, Tekyazman, 2019). Sosyal Kimlik Teorisi açısından bakıldığında kraliçe arı sendromu, kadın cinsiyetinin değersiz, erkeklerin ise egemen olduğu geleneksel yapıdaki örgütlerde, yönetim pozisyonuna yükselmeyi başarmış kadının kendisini grubun geri kalanıyla karşılaştırması ve toplumsal cinsiyet kalıp yargıları nedeniyle olumsuz değerlendirilen kadın grubundan ayrılarak, olumlu olan erkek grubuna girmeye çalışması sonucunda ortaya çıkmaktadır. Yönetim pozisyonuna ulaşmaya çalışan diğer kadınlara destek olmayan; aksine kendi yeteneklerinin ve bilgilerinin öne çıkmasını isteyen; tek kadın olmanın başarı göstergesi olduğuna inanan, bu nedenle örgütteki diğer kadınların kariyer ilerlemelerini engelleyen, sapma davranış olarak da nitelendirilen sosyal ve ilişkisel saldırganlık davranışları sergileyen kadın yönetici davranışları bu yaklaşım çerçevesinde incelenmektedir (Kızıldağ, 2018).

\subsection{Kadın Yöneticiler ile Kadın Astlar Arasındaki İlişkilere Yönelik Araştırmalar}

Yapılan literatür taramasında, genellikle kadın çalışanların kadın yönetici ile çalışma tercihlerini inceleyen araştırmalara rastlanmış ve aradan geçen pek çok yıla karşlık söz konusu tercihlerde önemli bir değişiklik olmadığ gözlemlenmiştir. Bu konudaki en eski araştırmalardan biri, Kanter'in 'Men and Women of the Corporation' isimli kitabında yer almaktadır. Kanter (1993: 201), 1942 yılında Donald Laird tarafından 521 kadın çalışan üzerinde yapılan bir araştırmanın sonuçlarını aktarmıştır. Bu araştırmada kadın çalışanların yüzde 99,8'i, kadın yöneticilerin çok kıskanç olduğu, her şeyi çok kişisel aldıkları, sağduyulu olmadıkları, etkililikle ve rutin detaylarla aşırı ilgilendikleri, sistemin kölesi oldukları, ufak detaylara takılıp kaldıkları, yakından denetledikleri, çok fazla hata buldukları, aşırı eleştirel oldukları, kendilerinin önemli bir birey olduğunu göstermek için astlarına bağırdıklarına inandıklarını ve bu nedenlerle erkek yöneticiyle çalışmayı tercih ettiklerini belirtmişlerdir. Kadın yöneticilere yönelik bu kalıp yargıları Laird 'aşırı tepki' olarak değerlendirirken Kanter ‘düşmanca' bulduğunu ifade etmiştir.

Benzer şekilde Eagly ve Karau (2002: 580) makalelerinde, kadın ve erkeklere yöneltilen kadın ya da erkek yönetici ile çalışma tercihleri ile ilgili soruya verilen cevapların yıllara göre dağılımını sunmuşlardır. Buna göre, 1982 yılında kadın çalışanların yüzde 15'i kadın yöneticiyi tercih ettiklerini dile getirirken 2000 yılında bu oranın yüzde 26'ya yükseldiği görülmüştür. Erkek yönetici tercihlerine bakıldığında ise 1982' de kadın çalışanların yüzde 52'si erkek yöneticiyi tercih ederken 2000 yılında bu oranının hemen hiç değişmediği (yüzde 50) görülmüştür. Erkek çalışanların tercihlerine bakıldığında ise 1982' de kadın yönetici ile çalışmayı tercih ettiklerini söyleyenlerin oranı yüzde 9 iken 2000 yılında bu oran yüzde 19'a yükselmiştir.

Literatürde, kadın yöneticilere yönelik kalıp yargıların yıllar içerisinde ne yönde değişim gösterdiğini inceleyen boylamsal araştırmalara da rastlanmaktadır. Örneğin Schein (1975: 340), başarılı bir yöneticinin sahip olması gereken niteliklere ilişkin algılamalar ile bu algılamalarda cinsiyet rollerine ilişkin kalıp yargıların rolünü araştırdı ̆̆ı çalışmasında, özellikle kadın astlarda, cinsiyetçi ön yargılar ile gerekli yönetsel nitelik algılamaları arasında daha güçlü bir ilişki olduğunu saptamıştır. Schein'in 1975 yılındaki bu araştırmasından sonra, kendisinin de aralarında bulunduğu araştırmacılar 1989 yılında aynı araştırmayı tekrarlamış ve zaman içerisinde kadın ve erkek yöneticilerin algılamalarında farklılık olup olmadığını incelemişlerdir. ABD'deki dokuz firmanın farklı departmanlarında görev yapan 420 erkek ve 173 kadın yönetici ile gerçekleştirilen bu araştırmada (Brenner vd.,1989: 667-668), erkek katılımcıların, başarılı yöneticilerin genellikle erkeklere atfedilen karakteristik, tutum ve mizaca sahip olmaları gerektiği görüşünü benimsemeyi sürdürdükleri ve 15 yıllık bir zaman zarfında bu konuda herhangi bir değişme olmadığı saptanmıştır. Buna karşılık, kadın yöneticilerin bakış açısında önemli bir değişim olduğu görülmüştür. Buna göre kadın katılımcıların, başarılı yöneticilerin sahip olması gereken özellik, tutum ve mizacı tanımlarken genel olarak hem erkek hem de kadınlara atfedilen nitelikleri kullandıkları saptanmıştır. Bunun da ötesinde, 
kadın katılımcılar, bir yöneticinin sahip olması gereken özelliklerin birçoğunun kendilerinde bulunduğunu ifade etmişlerdir.

Stoker ve arkadaşlarının (2012) çeşitli örgütlerde çalışan 3229 çalışan üzerinde yaptığı araştırmada da genel yönetici stereotipinin eril olduğu ve hala yönetici olarak en fazla erkeklerin tercih edildiği hipotezi doğrulanmıştır. Bununla birlikte (i) kadın çalışanların, (ii) kadın yönetici ile çalışma deneyimi olan kadın ve erkek astların ve (iii) kadın yönetici oranı yüksek bir örgütte çalışanların yöneticilerde dişil özellikleri ve kadın yöneticileri daha fazla tercih ettikleri saptanmıştır. Willemsen (2002: 285) tarafından Hollanda' da 143 yönetim eğitimi alan öğrenci ile yönetici rollerinin cinsiyet açısından değerlendirilmesine ilişkin bir araştırma yapılmıştır. Eril, dişil ve cinsiyetten bağımsız özelliklerden oluşan bir liste kullanılan araştırmada, başarılı yöneticiler için eril özelliklerin dişil özelliklerden daha fazla öne çıtığı görülmüştür. Benzer bir araştırma Almanya'da Gmür (2006) tarafından yapılmış ve 'iyi yönetici" özelliklerine ilişkin beklentilerin erkek stereotipine çok yakın olduğunu göstermiştir. Schein (2007) de 30 yıllık süreci uluslararası düzeyde analiz ettiği çalışmasında, ABD'deki erkek çalışanların, kadınların yönetsel pozisyonlar için daha az nitelikli olduğu görüşünü sürdürdüğünü tespit etmiştir. Bu görüşün ABD'nin yanı sıra İngiltere, Almanya, Çin ve Japonya'daki yönetim alanında eğitim gören erkek öğrenciler arasında da geçerli olduğu; kadınların yöneticilik özelliklerine daha az sahip olduğuna inandıkları saptanmıştır.

Diğer taraftan, literatürde kadın yöneticilere bakışın olumlu yönde değişmeye başladığını gösteren araştırma sonuçları da bulunmaktadır. Örneğin, Duehr ve Bono (2006: 815), kadın ve erkek yöneticiler ile öğrencilerin cinsiyet ve yönetim stereotiplerini öğrenmek için yaptığı araştırmada erkek yöneticilerin kadınlara ilişkin görüşlerinde son 30 yıl içerisinde önemli bir değişim olduğu saptanmıştır. Buna göre erkek yöneticilerin ‘başarılı yönetici' ve 'kadın yönetici' algılamaları arasında bir uyum olduğu ve kadın yöneticilerin görevodaklı liderlik özelliklerinin daha güçlü bir şekilde kabul edilmeye başlandığı tespit edilmiştir.

Kadın-erkek farklılaşması temelinde değerlendirilebilecek bu araştırma sonuçlarının yanı sıra kadın-erkek benzeşmesi çerçevesinde Kraliçe Arı Sendromu ile ilgili araştırma makalelerinin bulguları da incelenebilir. Örneğin Derks ve arkadaşları (2011b: 519), Hollanda' da çeşitli şirketlerde üst düzey pozisyonlarda çalışan 94 kadın ile, Kraliçe Arı fenomenini destekleyen örgütsel koşulları incelediği bir araştırma gerçekleştirmiştir. Tahminler doğrultusunda, Kraliçe Arı fenomeninin göstergelerine (artan cinsiyet stereotipleri ve eril öztanımlamalar) en fazla, kariyerlerinde ilerlerken yüksek derecede cinsiyet ayrımcllığına maruz kalan kadınlar arasında rastlandığı saptanmıştır. Bu sonuçlar, Sosyal Kimlik Teorisi ışığında tartışılmış ve Kraliçe Arı fenomeninin, kadınların iş yaşamında karşılaştıkları cinsiyet ayrımcılığına yönelik bireysel bir tepki olarak değerlendirilmiştir.

Benzer şekilde, Bickford (2011), İngiltere, Almanya ve Amerika'da yapılan bazı araştırmaların sonuçlarını paylaşmıştır. Bu sonuçlara göre kadın çalışanlar, kadın bir yöneticiyle çalıştıklarında daha fazla sağlık sorunu yaşayacaklarına inandıklarını belirtmişlerdir. American Management Association, kadınların yüzde 95'inin, kariyerlerinin belli bir noktasında başka bir kadın tarafından ayaklarının kaydırıldığını hissettiklerini saptamıştır. Bickford (2011), literatürdeki bu tür davranışların, başarılı kadınların büyük ölçüde erkek yönetim kültürünün egemen olduğu cinsiyetçi işyeri koşullarına uyum sağlama ihtiyacı hissetmelerinin bir sonucu olduğunu ifade etmiştir.

Türkiye'de ise İmamoğlu Akman ve Akman (2016: 748), Kraliçe Arı Sendromu bağlamında kadın öğretmenlerin kadın yöneticilerine ilişkin görüşlerinin belirlenmesi amacıyla nitel bir araştırma gerçekleştirmiştir. Araştırmanın sonuçlarına göre kadın yöneticilerin kıskanç, kaprisli, ayrıntıcı, kindar ve acımasız olduklarına yönelik olumsuz görüşlerle birlikte estetik ve sorumluluk sahibi olduklarına yönelik olumlu görüşler belirtilmiştir. Ayrıca kadın yöneticilerin tecrübesiz oldukları ve otorite sağlayamadıkları vurgulanmıştır. Bazı kadın öğretmenler kadın yöneticilerle çalışmanın zor olduğunu ifade etmiş; aynı ortamda birden fazla kadın yöneticinin olmasının örgütü olumsuz etkileyebileceğini söylemişlerdir. Araştırmanın sonuçlarına dayanarak yazarlar, kadın yöneticilere yönelik genel bir olumsuz tutumun egemen olduğunu ifade etmişlerdir.

Hurst ve arkadaşları (2018a: 501), cinsiyetçi bir toplumda, işyeri ilişkilerinin de cinsiyetçi bir şekilde algılanıp yaşanacağını ifade etmişlerdir. Yapılan araştırmalarda, kadın yöneticilerden, erkek yöneticilere kıyasla daha anlayışlı, destekleyici ve bağışlayıcı olmalarının beklendiği saptanmıştır. Bu araştırmalarda, kadın çalışanların, kadın yöneticilerinden hayatlarının karmaşıklığını anlamalarını, bu karmaşıklığa uyum sağlama 
esnekliği sağlamalarını ve aynı zamanda kadın yöneticiden daha yüksek düzeyde duygusal anlayış ve destek bekledikleri tespit edilmiştir. Diğer taraftan, cinsiyete dayalı beklentiler de dahil olmak üzere örgütlerde bu tür beklentiler dile getirilmemekte; bu da yanlış anlama ve çatışma olasılığını artırabilmektedir.

Gerek kadın astların gerekse kadın yöneticilerin çalışma yaşamlarında ve kariyer kararlarında oldukça önemli etkileri olan kadınlar arası hiyerarşik ilişkilerin daha detaylı araştırılması ve tartışılması gereğinden hareketle tasarlanan araştırmaya ilişkin bilgiler aşağıda sunulmaktadır.

\section{ARAŞTIRMA YÖNTEMI}

Nitel Araştırma Yönteminin kullanıldığı bu araştırmanın genel yaklaşımı, sınırlı sayıda örneğe bakarak genel hakkında fikir sahibi olunmasını sağlayan tümevarım yaklaşımıdır. Kadın astların kadın yöneticiler ile ilgili deneyimlerini, algılamalarını ve bunlara yüklediği anlamları ortaya çıkarmayı amaçlayan bu araştırmanın deseni ise fenomenolojidir. Fenomenoloji (olgu bilim), farkında olduğumuz ancak derinlemesine ve ayrıntılı bir anlayışa sahip olmadığımız olgulara odaklanmaktadır. Olgular yaşadığımız dünyada olaylar, deneyimler, algılar, yönelimler, kavramlar ve durumlar gibi çeşitli biçimlerde karşımıza çıkabilmektedir (Yıldırım ve Şimşek, 2013: 78).

Bu çalışmada inandırıcılı̆̆ın (iç geçerliliğin) başarılabilmesi için Yıldırım ve Şimşek (2013: 299) tarafından önerilen "derin odaklı veri toplama" stratejisinden yararlanılmıştır. Bu doğrultuda, açık uçlu sorularla toplanan verilerin, araştırma sorusu açısından anlamı, birbirleriyle olan ilişkileri, bir bütün olarak sergiledikleri örüntüler ortaya çıkarılmaya çalışılmıştır. Elde edilen sonuçlar araştırmacı tarafından sürekli olarak birbirleriyle karşılaştırılmış, yorumlanmış ve kavramsallaştırılmıştır. Araştırmada inandırıcılığı sağlamada ikinci bir strateji olarak "uzman incelemesi" yöntemine başvurulmuştur. Oluşturulan kategorilerin ne derece işlevsel olduğunu belirlemek amacıyla, veri setinden dört belge (katılımcı formu) rastgele seçilerek Yönetim ve Organizasyon alan yazınına hakim ve ayrıca MAXQDA programını kullanmada uzman üç ayrı akademisyene gönderilmiştir. Uzmanlar tarafından yapılan kodlamalar ile araştırmacının yaptığı kodlamalar karşılaştırılmış ve uzmanlardan gelen öneriler doğrultusunda kodlamalar gözden geçirilerek gerekli düzenlemeler yapılmıştır. Bu aşamadan sonra, oluşturulan yeni kod listesi, tekrar Yönetim ve Organizasyon alanından ve Toplumsal Cinsiyet, Kadın İstihdamı konularında uzman olan bir başka akademisyene gönderilerek uzman incelemesi gerçekleştirilmiştir. Alınan geribildirim doğrultusunda kod listesi revize edilerek MAXQDA programı üzerinde gerekli değişiklikler yapılmıştır.

Araştırmada sonuçların aktarılabilirliğini artırmak için, literatürde önerilen iki yöntemden yararlanılmıştır: (1) Araştırma bulgularının raporlanmasında, katılımcıların belirlenen kategoriler ile ilgili ifadelerinden doğrudan alıntılar yapmak, (2) Amaçlı örnekleme yöntemlerini kullanmaktır.

\section{1. Örneklem}

Bu araştırmada Patton'un (1987) sınıflandırmasına dayanarak Amaçlı Örnekleme yöntemlerinden Maksimum Çeşitlilik Örneklemesi ve Ölçüt Örnekleme yöntemleri kullanılmıştır. Buna göre araştırmanın, "iş yaşamında kadın yöneticiler ile çalışış ve/veya çalışmaya devam eden" (örneklem ölçütü) ve imkanlar dahilinde ulaşılması mümkün olan farklı sektörlerden ve mesleklerden kadın çalışanlar ile (maksimum çeşitlilik ölçütü) gerçekleştirilmesi tasarlanmıştır. Araştırma sorusunun yanıtı olabilecek kavramların ve süreçlerin tekrar etmeye başladığı aşamaya kadar (doyum noktası) veri toplamaya devam edilmiştir. Bu çerçevede, 20 farklı sektörden ve farklı meslek gruplarından toplam 40 kadın çalışana ulaşılmıştır.

Katılımcıların mesleki ve sektörlere göre dağılımları incelendiğinde (Tablo 1), farklı üniversitelerde görev yapan 7 katılımcıdan üçünün akademisyen, dördünün idari personel olduğu görülmektedir. Yine katılımcıların 6'sı eğitim kurumlarında çalışan sınıf ve branş öğretmenleridir. Sağlık ve Finans sektörlerinden üçer katılımcı bulunmaktadır. Belediye, Danışmanlık Hizmetleri, Giyim, Medikal Ürünler ve Savunma sanayiden ikişer; diğer sektörlerden ise birer katılımcı bulunmaktadır. 
E. Tolay $12 / 3$ (2020) $2276-2296$

Tablo 1. Katılımcıların Meslek ve Sektör Bilgileri

\begin{tabular}{|c|c|c|c|c|c|}
\hline & Meslek & Sektör & & Meslek & Sektör \\
\hline K1 & Banka Memuru & Finans & K21 & Banka Memuru & Finans \\
\hline K2 & Devlet Memuru & Üniversite & K22 & Tekstil Mühendisi & Tekstil \\
\hline K3 & Güverte-Vardiya Zabiti & Denizcilik & $\mathrm{K} 23$ & Öğretmen & Eğitim \\
\hline K4 & Hemşire & Sağlık & K24 & Medikal Delege & Medikal Ürünler \\
\hline K5 & Kimya Mühendisi & Üniversite & K25 & Genel Müdür Yrd. & Reklamcilık \\
\hline K6 & Akademisyen & Üniversite & K26 & Sınıf Öğretmeni & Eğitim \\
\hline K7 & Hemşire & Sağlık & K27 & Sınıf Öğretmeni & Eğitim \\
\hline K8 & Abone Servisi Uzm. Yrd. & Enerji & K28 & Tekniker-Memur & Belediye \\
\hline K9 & Hemşire & Sağlık & K29 & Akademisyen & Üniversite \\
\hline K10 & Muhasebe Sorumlusu & Giyim & K30 & Devlet Memuru & Belediye \\
\hline K11 & İş ve Meslek Danışmanı & Danışmanlık & K31 & Muhasebe Elemanı & İnşaat \\
\hline K12 & Akademisyen & Üniversite & K32 & Öğretmen & Eğitim \\
\hline K13 & Devlet Memuru & Üniversite & K33 & Devlet Memuru & Savunma Sanayi \\
\hline K14 & İK ve İdari İşler & Yazılım & K34 & Devlet Memuru & Üniversite \\
\hline K15 & İşe Alım Uzmanı & Elektrik-elektronik & K35 & Departman Müdürü & Giyim \\
\hline K16 & Muhasebe Elemanı & Otomotiv & K36 & Öğretmen & Eğitim \\
\hline K17 & Muhasebe Uzmanı & Danışmanlık & K37 & Öğretmen-Müdür Yrd. & Eğitim \\
\hline K18 & Çağrı Merkezi Takım Lideri & Beyaz Eşya & K38 & Devlet Memuru & Savunma Sanayi \\
\hline K19 & Medikal Delege & Medikal Ürünler & K39 & Güzellik Uzmanı & Güzellik \\
\hline K20 & Banka Müdürü & Finans & K40 & Girişimcilik Birim. Uzm. & Teknoloji \\
\hline
\end{tabular}

Tablo 2' de katılımcı profiline ilişkin bilgiler yer almaktadır. Katılımcıların eğitim düzeyleri incelendiğinde, yüzde 82,5'inin lisans ve lisans üstü dereceye sahip olduğu; kalan yüzde 17,5'inin ise lise ve ön lisans mezunu olduğu görülmektedir. Araştırmaya katılanların yaklaşık yarısı 35-44 yaş aralığındadır. Yüzde 32'si 25-34; yüzde 20 'si ise 45 yaş ve üzerindedir.

Araştırmaya katılanlara toplam çalışma süreleri ve kadın yöneticilerle ne kadar süre çalıştıkları da sorulmuştur. Verilen yanıtlara göre katılımcıların yüzde 72,5' i 10 yıldan fazla; yüzde 27,5'i ise 10 yıl ve altında çalışma süresine sahiptir. Araştırmaya katılanların bir kadın yönetici ile birlikte çalışma sürelerine bakıldığında ise yüzde 40'ının 2-5 yıl arasında; yüzde 35'inin 5-10 yıl arasında; yüzde 20'sinin 10 yıldan fazla bir süredir kadın yönetici ile çalıştığı saptanmıştır. 2 katılımcının kadın yönetici ile çalışma deneyimi ise 2 yıldan kısadır.

Tablo 2: Katılımcı Profiline İlişkin Bilgiler ( $\mathrm{N}=40)$

\begin{tabular}{|c|c|c|c|c|c|c|c|}
\hline Değişken & Kategori & $\mathrm{n}$ & $\%$ & Değişken & Kategori & $\mathrm{n}$ & $\%$ \\
\hline \multirow{7}{*}{ Yaş } & $25-29$ yaş & 8 & 20.0 & \multirow{6}{*}{ Çalışma Süresi } & $1-5$ yil & 3 & 7.5 \\
\hline & $30-34$ yaş & 5 & 12.5 & & 6-10 yıl & 8 & 20.0 \\
\hline & $35-39$ yaş & 10 & 25.0 & & $11-15 \mathrm{y} 1 \mathrm{l}$ & 11 & 27.5 \\
\hline & $40-44$ yaş & 9 & 22.5 & & $16-20 \mathrm{yll}$ & 5 & 12.5 \\
\hline & $45-49$ yaş & 6 & 15.0 & & 20 yıl ve üzeri & 13 & 32.5 \\
\hline & 50 yaş ve üzeri & 2 & 5.0 & & & & \\
\hline & & & & Kadın Yönetici ile & & & \\
\hline \multirow[t]{5}{*}{ Eğitim } & Lise & 4 & 10.0 & \multirow[t]{5}{*}{ Çalışma Süresi } & $0-2$ y1l & 2 & 5.0 \\
\hline & Ön Lisans & 3 & 7.5 & & $2-5$ y1l & 16 & 40.0 \\
\hline & Lisans & 21 & 52.5 & & $5-10$ yıl & 14 & 35.0 \\
\hline & Yüksek Lisans & 8 & 20.0 & & 10 yıl ve üzeri & 8 & 20.0 \\
\hline & Doktora & 4 & 10.0 & & & & \\
\hline
\end{tabular}




\subsection{Veri Toplama Tekniği}

Araştırmanın amacını bildiren, yönergelerin ve açık uçlu soruların yer aldığı bir form, katılımcılara elektronik posta aracılığ 1 ile gönderilmiştir. Formda ayrıca yaş, sektör, meslek, çalışma süresi ve eğitim düzeyini belirlemeye yönelik demografik sorulara da yer verilmiştir. Veri toplama süreci 10 Aralık 2019 tarihinde başlatılmış ve 31 Aralık 2019 tarihinde sonlandırılmıştır. Bireysel varsayımların ve önyargıların araştırmaya yansımasını önlemek amacıyla soruların hazırlanmasında büyük bir titizlik gösterilmiş ve katılımcılara, doğrudan kadın yöneticileri ile yaşadıkları olumsuz deneyimleri anımsatacak yönlendirici sorular sorulmamasına özen gösterilmiştir.

\subsection{Analiz Tekniği}

$\mathrm{Bu}$ çalışmada nitel analiz tekniği olarak İçerik Analizi kullanılmıştır. Bu doğrultuda, 40 katılımcıdan toplanan nitel veriler, MAXQDA 2020 Nitel Veri Analizi Programına aktarılmış ve her bir katılımcının verdiği cevaplar okunarak kodlama yapılmıştır. Sonraki aşamada, kendi içerisinde anlamlı bir bütün oluşturan kodlar bir araya getirilerek kategoriler (temalar) saptanmıştır. Üçüncü aşamada, nitel araştırmanın geçerliliğini ve güvenilirliğini sağlamaya yönelik stratejiler saptanıp uygulanarak kodların ve temaların düzenlenmesi tamamlanmıştır. Son aşamada ise bulgular tanımlanmış ve yorumlanmıştır.

Araştırma bulgularının özetlendiği tablolarda "kod frekansı", bir katılımcının konuşması içerisinde belli bir kavrama / koda kaç kez değindiğini; "katılımcı frekansı" ise bir kavrama kaç katılımcı tarafından değinildiğini göstermektedir. Ayrıca, bazı tablolarda verilen yüzde değerlerinin toplamının 100 olmaması, katılımcıların birden fazla kategori altında değerlendirilebilecek yanıtlar vermiş olmasından kaynaklanmaktadır.

\section{BULGULAR}

Analizlerden elde edilen bulgular, araştırmanın soruları esas alınarak şu başlıklar altında sunulacaktır: (i) Kadın yönetici ile çalışmanın nasıl bir duygu olduğu sorusuna ilişkin bulgular, (ii) Kadın ve erkek yöneticiler arasındaki farklara ilişkin bulgular, (iii) Erkek ve kadın yöneticilerin olumlu ve olumsuz özelliklerine ilişkin bulgular, (iv) Kadın yönetici ile çalışmanın avantaj ve dezavantajlarına ilişkin bulgular ve (v) Kadın veya erkek yönetici ile çalışma tercihlerine ilişkin bulgular.

\subsection{Kadın Yönetici ile Çalışmanın Nasıl Bir Duygu Olduğu Sorusuna İlişkin Bulgular}

Katılımcılara yöneltilen "Bir kadın olarak kadın bir yönetici ile çalışmak sizce nasıl bir duygu?" sorusuna verilen yanıtlara ilişkin değerler Tablo 3'te gösterilmektedir. Frekans ve yüzde değerleri incelendiğinde, katılımcıların yüzde 45'i (18 kişi) kadın yönetici ile çalışmanın kendisinde iyi, güzel, keyifli, rahatlatıcı ve güven verici duygulara yol açtığını (22 kez) belirtmiş̧tir. Buna karşılık yüzde 47,5'i (19 kişi) kötü, rahatsız ve tedirgin edici, gerginlik yaratan, rekabetçi, değersiz hissettiren duygulara yol açtı̆̆ını ve kadın yönetici ile çalışmanın zorlayıcı bir duygu olduğunu (25 kez) ifade etmiştir. Bunların dışında 11 katılımcı, bunun kişiden kişiye (örneğin kadın yöneticinin demografik özellikleri) veya koşullara göre (karşılıklı ilişkide dengenin sağlanıp sağlanamamış olması veya faaliyette bulunulan sektör gibi) değişebileceğini belirtmiş̧lerdir. Dikkat çeken bir unsur, kadın yönetici ile çalışmanın hem çok olumlu hem de çok olumsuz olduğunu düşünen bir katılımcı yelpazesi olmasıdır. Örneğin aşağıdaki iki katılımcının bu konudaki görüşleri, birbirinden oldukça farklidir:

K1: "Erkek yöneticiler her zaman çok iyidir demiyorum ama kadınlarla çalışmak, her zaman bir erkek yöneticiyle çalışmaktan çok daha zordur."

K28: "Bana göre kadın yöneticiyle çalışmak her zaman daha iyidir çünkü anlayışlı bir çalışma ortamı yaratmaktadır."

Kadın yönetici ile çalışmanın nasıl bir duygu olduğu sorusuna, bunun yöneticinin cinsiyeti ile değil, farklı birtakım özellikleri ile ilişkili olduğunu belirten katılımcılar da olmuştur. Örneğin, öğretmen olan bir katılımcı, birlikte çalıştığı farklı kadın yöneticilerden yola çıkarak şöyle bir sonuca ulaşmıştır:

K36: Bu, karşınızdaki kişiye (kadına) göre değişiyor. Çalıştı̆̆ım iki kadın yöneticiyle çalışmak oldukça keyifliydi. Çünkü yapı olarak benziyorduk. İş odaklı insanlardı. Diğer yandan, çalıştığım iki diğer kadın yönetici ile çalışmak ise oldukça zordu." 
Otomotiv sektöründe muhasebe elemanı olan Katılımcı 16'nın aşağıdaki ifadesi ise kadın yöneticilerin sahip oldukları özelliklerin, kadın çalışanlar üzerindeki duygusal etkilerini ortaya koyması açısından çarpıcıdır ve hem olumlu hem de olumsuz duygular kategorisinde kodlanmıştır:

K16: "Sizinle aynı şekilde düşünebilen biriyle çalışmak... İş odaklı olmanın ötesinde olaylara duygusal bakabilen biriyle çalışmak... Sizi anlayabilecek olmasının verdiği güven ve bazen aşırı duygusal ve kurgusal bakabiliyor olmasının verdiği endişe..."

Tablo 3. Kadın Yönetici ile Çalışmanın Nasıl Bir Duygu Olduğuna İlişkin Bulgular

\begin{tabular}{|llccc|}
\hline & KATEGORİLER & $\begin{array}{c}\text { KOD } \\
\text { FREKANSI }\end{array}$ & $\begin{array}{c}\text { KATILIMCI } \\
\text { FREKANSI }\end{array}$ & $\begin{array}{c}\text { KATILIMCI } \\
\text { YÜZDESİ }\end{array}$ \\
\hline 1 & Olumlu Duygular & 22 & 18 & 45.0 \\
2 & Olumsuz Duygular & 25 & 19 & 47.5 \\
3 & Kişiye ve Koşullara göre Değişir & 13 & 11 & 27.5 \\
& Toplam & $\mathbf{6 0}$ & & \\
\hline
\end{tabular}

\subsection{Kadın ve Erkek Yönetici ile Çalışmak Arasındaki Farklara İlişkin Bulgular}

Katılımcılara yöneltilen "Sizce kadın yöneticiyle çalışmak ile erkek yöneticiyle çalışmak arasında farklar var mıdır?" sorusuna 40 katılımcıdan 25'i yanıt vermiştir. Buna göre, toplam katılımcıların yüzde 52,5'i ve yanıt veren katılımcıların yüzde $84^{\prime}$ ü (21 kişi), kadın ve erkek yöneticiler arasında "kesinlikle fark olduğunu" belirtmişler ve bu farklılıkların neler olduğunu açılayarak kadın ve erkek yöneticilerin olumlu ve olumsuz özellikleri ile ilgili kategorilerin belirlenmesine katkıda bulunmuşlardır. Diğer taraftan, "Fark vardır ancak görev bilinci ile karşılıklı saygı korunduğu sürece pek bir önemi olmadığını" söyleyen (Katılımcı 30) ya da "Kadın ve erkek yönetici arasında cinsiyetin, toplum normlarının, geleneklerin, kuşakların getirdiği farklar bulunduğunu" dile getiren (Katılımcı 6) ve bu nedenle birden fazla kategori altında kodlanan ifadeler de bulunmaktadır. Araştırmaya katılanların yüzde 7,5'i (3 kişi) kadın ve erkek yöneticiler arasında fark olmadığını; yüzde 15'i (6 kişi) ise farklılık varsa bile bunun cinsiyet ile ilgili değil; karakter, kişilik, demografik özellikler, yöneticilik eğitimine ve tecrübesine sahip olup olmama gibi faktörlerle ilgili olduğunu ifade etmişlerdir. Tablo 4'te “özellikler belirleyicidir" kategorisine örnek olarak sınıf öğretmeni olan bir katılımcının ifadesi verilebilir:

K26: "Bence fark yok. Kadın ya da erkek kimliklerinden öte, karakterleriyle alakalı bir durum olduğunu düşünüyorum. Erkek ya da kadın yönetici aynı hisleri hissettirebilir çalışan üzerinde. Kadın yöneticilerin daha duygusal ve kaprisli olacağı yönünde düşünceler olduğunu tahmin ediyorum. Oysa aynı yapıda olan pek çok erkek var günümüzde."

Tablo 4: Kadın ve Erkek Yönetici ile Çalışmak Arasındaki Farklar

\begin{tabular}{|llcc|}
\hline KATEGORİLR & $\begin{array}{c}\text { KATILIMCI } \\
\text { FREKANSI }\end{array}$ & $\begin{array}{c}\text { KATILIMCI } \\
\text { YÜZDESI }\end{array}$ \\
\hline 1 & Fark var & 21 & 52.5 \\
2 & Fark yok & 3 & 7.5 \\
3 & Özellikler belirleyicidir & 6 & 15 \\
\hline
\end{tabular}

Cinsiyetçi önyargılardan uzak olduğu görülen bu ifadenin konuya objektif yaklaşım açısından çarpıcı olduğu düşünülmektedir. Benzer biçimde, branş öğretmeni olan bir başka katılımcı da farklılığın kaynağının cinsiyette aranmaması gerektiğine işaret etmiştir:

K23: "Ben herhangi bir fark olduğunu düşünmüyorum. Cinsiyetten kaynaklı değil de karakter belirleyicidir diye düşünüyorum. Karakteriniz yöneticiliğe uygunsa her durumda kendinizi var edersiniz. Kadın olmanın, yöneticilikte ekstra bir artı veya eksisi olduğunu düşünmüyorum."

\subsection{Erkek ve Kadın Yöneticilerin Olumlu ve Olumsuz Özelliklerine İlişkin Bulgular}

“Eğer kadın ve erkek yönetici arasında fark olduğunu düşünüyorsanız, bu farklılığın sebepleri neler olabilir?” sorusuna verilen cevapların kodlanması ile erkek ve kadın yöneticilerin olumlu ve olumsuz özellikleri ile ilgili kategoriler belirlenmiştir.

Erkek yöneticilerin olumlu özellikleri incelendiğinde (Tablo 5), erkek yöneticilerin kadın yöneticilere kıyasla daha profesyonel bir yaklaşım sergilediğine $16 \mathrm{kez}$ değinildiği ve bu unsurların, katılımcıların yüzde 27,5'i 
tarafından (11 kişi) dile getirildiği görülmektedir. Profesyonel yaklaşımın alt kodları içerisinde yer alan "duygularını işe yansıtmama" konusuna 9; "ilişkide mesafeli olma, sınırları aşmama" konusuna ise 7 kez değinilmiştir. Aşağıdaki katılımcı ifadeleri, erkek yöneticilerin 'duygularını işe karıştırmamaları' alt kategorisinde toplanan görüşler hakkında fikir vermektedir:

K3: "Kadın yöneticilerin özel hayatlarında yaşadıkları olumsuz durumları işlerine daha çok yansıttıkların düşünüyorum. Erkekler bu konuda daha profesyonel".

K6: "Erkek yönetici ile iletişim kurarken daha kısa, daha net, daha kararlı ve duygudan uzak olmak gerekli. Sizi rakip olarak görme durumları daha az. Daha önce yapılan ve yaşanılanlar kolay unutulduğu için iletişim süreci tekrar tekrar yeniden başlayabiliyor."

Diğer taraftan, erkek yöneticilerin, kadın çalışanlarla ilişkilerinde mesafeli olmaları ve sınırların aşılmaması ile ilgili ifadeler incelendiğinde, katılımcıların bu durumdan memnuniyet duydukları anlaşılmaktadır. Bir başka deyişle, erkek yöneticilerin kadın çalışanlarla mesafeli ve hatta duygudan uzak iletişim tarzının, kadın çalışanlar tarafından oldukça olumlu ve rahatlatıcı karşılandığını söylemek mümkündür. Örneğin, banka memuru olan Katılımcı 1, "Kadın yöneticiden izin almak erkek yöneticiden izin almaktan daha zordur. Çünkü neden izin aldığına dair detay sorar. Bu da personeli rahatsız eder. Çünkü özel olabilir ve anlatmak istemeyebilir. Erkek yöneticiler daha kolay izin verir ve detay sormaz." diyerek kadın yöneticiyle çalışmanın bazen en önemli avantajı olarak dile getirilen "daha rahat iletişim kurabilme" nin, bazen karşılıklı ilişkilerde rahatsızlık yaratabildiğine işaret etmiştir. Buna karşılık, erkek yönetici ile iletişimde bu düzeyde bir rahatlık söz konusu olmadığından profesyonel iş ilişkisi daha sağlıklı olarak yürütülebilmektedir. Nitekim, devlet memuru olan Katılımcı 2'nin "Erkek yönetici ile ister istemez aranızda bir mesafe vardır. Bu mesafe daha seviyeli ve daha sağlıkl bir iş ilişkisi sunar." ifadesi ile kimya mühendisi olan Katılımc1 5'in "Erkek yönetici daha mesafeli ve daha özenli bir yaklaşımda bulunuyor. Karşı tarafın sınırlarını aşmadan iş isteminde bulunuyor ve işi o şekilde yönetiyor." ifadesi bu düşünceyi desteklemektedir.

Tablo 5. Erkek Yöneticilerin Olumlu Özellikleri

\begin{tabular}{|clccc|}
\hline KATEGORİLR & $\begin{array}{c}\text { KOD } \\
\text { FREKANSI }\end{array}$ & $\begin{array}{c}\text { KATILIMCI } \\
\text { FREKANSI }\end{array}$ & $\begin{array}{c}\text { KATILIMCI } \\
\text { YÜZDESİ }\end{array}$ \\
\hline 1 & Profesyonel Yaklaşım & 16 & 11 & 27.5 \\
2 & Anlayışlı Olma ve Rahatlık & 14 & 10 & 25 \\
3 & Açı ve Özenli İletişim & 13 & 12 & 30 \\
4 & Göreve Dönüklük / Sonuç Odaklılık & 8 & 8 & 20 \\
5 & Başarıları Takdir Etme & 3 & 2 & 5 \\
& Toplam & $\mathbf{5 4}$ & & \\
\hline
\end{tabular}

Erkek yöneticilerin diğer bir olumlu özellikleri "anlayışlı ve rahat olmaları"dır ve bu konuya 10 katılımcı tarafından 14 kez değinilmiştir. Erkek yöneticilerin daha anlayışlı olduğuna ve onlarla çalışmanın daha kolay olduğuna ilişkin olarak enerji sektöründe uzman yardımcısı olan Katılımcı 8'in ifadesi dikkat çekicidir:

"Erkek yöneticilerde de "ego" gözlemlense de kadın yöneticilere göre detaycı olmadıkları için çalışmak daha sorunsuz oluyor. Genel olarak düşündü̈̆̈̈müzde erkek yönetici, kadın yöneticiye göre daha esnek, daha anlayışlı, daha az evhamlı ve personele az da olsa özgürlük alanı sağhlyor."

12 katılımcı tarafından değinilen "Açık ve özenli iletişim" kodu altında sınıflandırılan ifadeler, erkek yöneticilerin iletişim kurmaya, astlarının farklı önerilerine ve hatta eleştirilerine, kadın yöneticilere kıyasla daha açık olduklarına ilişkin katılımcı düşüncelerini yansıtmaktadır. Ayrıca erkek yöneticilerin "çatışma" durumlarında özellikle kadın astlarına daha özenli ve insancıl bir yaklaşım sergiledikleri ve örtülü iletişimden kaçındıkları, daha dolaysız, kısa ve net bir iletişim tarzı benimsediklerine ilişkin ifadeler de bu kategori altında değerlendirilmiştir. Aşağıda bu ifadelerden bazı örnekler yer almaktadır.

K13: “Geçmiş deneyimlerime göre erkekler kadınları incitmekten çekiniyor. Sadece iş konusunda daha ciddi tepkiler alabiliyorsunuz. Ĕ̆ger duygusal anlamda sizin yaşamınızı etkileyecek bir olumsuzluk yaşattılarsa da kendilerini çok kötü hissediyorlar." 
K36: “Erkek yöneticilerin daha net olduklarını ve olayları kişisel algılamadıklarını düşünüyorum. Erkek yöneticilerle iletişim kurarken düşündüklerimi direkt söylediğimi, kadın yöneticilerle ise çoğu kez "böyle desem ne der, şöyle desem ne olur" diye düşünmek zorunda kaldığımı belirtebilirim."

Erkek yöneticilerin olumsuz özellikleri ise üç ana kod altında sınıflandırılmıştır (Tablo 6). Bunlar, görev odaklı iletişim, empati kuramama ve kadınsal sorunları paylaşamamadır. Görev odaklı iletişim kategorisi altında katılımcıların en fazla değindiği konuların başında, erkek yöneticilerin iletişim tarzının duygudan uzak, iş/sonuç odaklı olması, çalışanlarla yeterli iletişim kurmamaları, dinlemeye hevesli olmamaları gelmektedir. Bu bağlamda, Katılımcı 28 tarafından dile getirilen aşağıdaki ifade, kadın ve erkek yöneticilerin iletişim tarzındaki farklılığın, astların iş doyumu üzerindeki etkisine ilişkin önemli bir öngörü sağlamaktadır:

"Kadın yönetici daha duygusal yaklaşır ve samimiyeti hissettirirken, erkek yönetici yaklaşımında duygulara pek yer vermez ve realist tutumunu hissettirir. Kadın yöneticinin bu tutumuyla saatlerce çalışma hissim olurken, erkek yöneticinin yaklaşımı ile mesai saatlerini baz alarak çalışırım."

Yazılım sektöründe İK sorumlusu olan Katılımcı 14, erkek yöneticilerin kadın yöneticilere kıyasla izin verme ve iş konusunda daha rahat olmaları ile ilgili düşüncesini şöyle belirtmiştir: "Erkek yöneticiler izin ve iş konusunda daha rahat görünebiliyorlar ama bu, daha rahat olduklarından değil; çalışanla uğraşmayı veya yüzleşmeyi tercih etmediklerinden (sosyal ve duygusal zeka eksikliği diye değerlendiriyorum)." Bu ifadenin, kadın yöneticilerin "izin verme" konusundaki katı tutumlarına veya detay sormalarına ilişkin eleştirilerle birlikte değerlendirildiğinde farklı bir bakış açısı sunduğu söylenebilir.

Tablo 6. Erkek Yöneticilerin Olumsuz Özellikleri

\begin{tabular}{|clccc|}
\hline KATEGORİLER & $\begin{array}{c}\text { KOD } \\
\text { FREKANSI }\end{array}$ & $\begin{array}{c}\text { KATILIMCI } \\
\text { FREKANSI }\end{array}$ & $\begin{array}{c}\text { KATILIMCI } \\
\text { YÜZDESİ }\end{array}$ \\
\hline 1 & Görev Odaklı İletişim & 9 & 5 & 12.5 \\
2 & Empati Kurmama & 2 & 2 & 5.0 \\
3 & Kadınsal Sorunları Paylaşamama & 2 & 2 & 5.0 \\
& Toplam & $\mathbf{1 3}$ & & \\
\hline
\end{tabular}

Kadın yöneticilerin olumlu özelliklerine gelindiğinde ise bu konuya ilişkin 10 kategori belirlenmiş olup (Tablo 7) bunların içerisinde "empati kurma ve anlayış gösterme" olarak isimlendirilen kategorinin en sık tekrarlanan kod olduğu görülmektedir (16 katılımcı tarafından $21 \mathrm{kez}$ ). İfadeler incelendiğinde, katılımcılar sıklıkla kadın yöneticilerin empati kurabilme yeteneğinden bahsetmişler ve "Kadın, kadının halinden daha iyi anlar" cümlesini kurmuşlardır. Aşağıda bu kategori ile ilgili katılımcı ifadelerinden örnekler yer almaktadır:

K12: “Bizler de kadın olunca, kadın kadının halinden daha iyi anlar. Hoşgörülü olup, anlayıs gösterir, empati kurabilir. Bazen duruma göre, eğer annelik iç güdüsü yüksek bir birey ise o güdü ile şefkatle sarılıp kollayabilir."

K14: “Çalışanlarının ruh haline, özel hayatlarında yaşadıkları hem problemlere, üzüntülere hem de mutluluklara ve sevinçlere karşı daha duyarlı ve ilgililer. Çalışanları bu açıdan da takip ediyorlar. Daha anlayışlı ve hoşgörülüler. Empati kurabiliyorlar (...). Benim yaşadıklarıma benzer deneyimleri yaşadığını gördü̆̆̈̈mde, yalnız olmadığımı hissediyorum."

K16: "Avantajları, yaşadığınız ayn fiziksel ve duygusal süreçlerden geçebiliyor olması ve empati kurabilme yetisine sahip olması, anlayabilmesi, kadın yönetici ile iletişimin daha hızl ilerleyebiliyor olması, daha rahat olunabiliyor olması." (...) "Kadın yöneticiler ile çalışmak, daha karmaşık olsalar da çalışanlarının doğum, özel dönem, duygusal ilişki vb. süreçlerinde daha fazla empati yapabildiğini ve anlayışl olabildiğini gözlemliyorum."

K27: “Öncelikle kadın yöneticilerin kadın çalışanlarla daha fazla empati kurabildiklerini düşünüyorum. Sadece gözlerinize bakmakla bile kaygılarınızl, sevinç ve hüzünlerinizi daha rahat anlayabiliyorlar." (...) "Erkek yöneticilere nazaran sizi daha iyi dinleyebiliyor. Heyecanla arka arkaya siraladığınız cümlelerde bile söylemek istediğinizin özünü hemen anlıyorlar." (...) "Sizi anladığını ve yanınızda olacağını hissetmek güven ortamı sağlıyor."

Kadın yöneticilerin diğer olumlu özellikleri incelendiğinde, detaylı ve çok yönlü düşünebilme, şefkatli, düzenli, disiplinli, duygusal, nazik, iyi bir iletişimci ve astlara destek olma özelliklerinin katılımcılar tarafından en az 5 kez 
dile getirilen konular olduğu görülmüştür. Katılımcı 14, kadın yöneticilerin düzenli ve disiplinli olmaları hakkındaki görüşünü, "Bence, kadın yöneticiler kendilerini erkeklere göre daha fazla iş yaşamına adıyorlar. Sorumluluk duygular kendilerine zarar verecek şekilde gelişmiş olabiliyor ve daha disiplinli olabiliyorlar" biçiminde dile getirmiş ve bunun nedenini "erkek egemen inşası olan çalışma yaşamında kendini ispat etmenin ve cinsiyetçi önyargılarla mücadele etmenin bir uzantısı olmaya" dayandırmıştır. Kadın yöneticilerin iş yaşamında karşılaştıkları bazı zorluklara açıklama getiren bu ifadenin, literatür tarafından da desteklendiği söylenebilir.

Diğer taraftan, Katılımcı 28'in "şefkatli olma" kategorisi altında değerlendirilen "Çalıştı̆̆ım kadın yöneticilerimin çocuklarının olması sebebiyle evde üstlendikleri anne sorumluluğunu iş yerinde de hissettirmişlerdir. Çalışanların çocukları olarak görüp onların her türlü iş-özel sorunlarına karşı ilgili yaklaşımları, çz̈züm bulmaya çalışmaları, anaç tutumları sebebiyle gördü̈̆̈̈̈m sevgi, beni her zaman aile ortamında hissettirmiştir." ifadesinin, kadın yöneticilerin özel yaşam sorumluluklarının ve özellikle "annelik" rollerinin, çalışanlar tarafından gözlemlendiğinin ve bunun kimi zaman hoşa giden bir durum olabildiğini göstermektedir.

Tablo 7. Kadın Yöneticilerin Olumlu Özellikleri

\begin{tabular}{|rlccc|}
\hline KATEGORİLER & $\begin{array}{c}\text { KOD } \\
\text { FREKANSI }\end{array}$ & $\begin{array}{c}\text { KATILIMCI } \\
\text { FREKANSI }\end{array}$ & $\begin{array}{c}\text { KATILIMCI } \\
\text { YÜZDESI }\end{array}$ \\
\hline 1 & Empati Kurma ve Anlayış Gösterme & 21 & 16 & 40.0 \\
2 & Detayli ve Çok Yönlü Düşünebilme & 9 & 7 & 17.5 \\
3 & Şefkatli Olma & 7 & 5 & 12.5 \\
4 & Düzenli, Disiplinli Olma & 6 & 5 & 12.5 \\
5 & Duygusal Olma & 5 & 4 & 12.5 \\
6 & Nazik Olma & 5 & 4 & 10.0 \\
7 & İyi Bir İletişimci Olma & 5 & 3 & 10.0 \\
8 & Astlara Destek Olma & 5 & 5 & 7.5 \\
9 & İşe Adanmişlik & 2 & 2 & 5.0 \\
10 & Demokratik Olma & 1 & 1 & 2.5 \\
& Toplam & $\mathbf{6 6}$ & & \\
\hline
\end{tabular}

Kadın yöneticilerin olumsuz olarak algılanan özellikleri incelendiğinde (Tablo 8), "profesyonel olmayan davranışlar" kategorisi altında sınıflandırılan özelliklere katılımcıların yaklaşık yüzde 60'ının 49 kez değindiği görülmektedir. Bu kategori altında 5 alt kod bulunmaktadır. Bunlar, "kıskanç ve rekabetçi olma” (15 katılımcı tarafından $17 \mathrm{kez}$ ), "duygularıyla hareket etme" (17 katılımcı tarafından $24 \mathrm{kez})$, "yüksek ego" (5 kez), "sert ve agresif olma" (4 kez) ve "hemcinslerin dış görünüşü ve özel hayatı hakkında konuşmaları" (3 kez) biçiminde isimlendirilmiştir. Katılımcı ifadeleri incelendiğinde, kadın yöneticilerin kıskanç ve rekabetçi olmaları ile ilgili şu çarpıcı örnekler verilebilir:

K6: "Kendini size rakip olarak gördüğü̈nde iletişim süreci bozulabiliyor ve mobbinge gidebilen bir süreç başliyor."

K17: “Kadın yöneticiler onların bilmediği bir şeyi bulduğunuzda öfkelenebiliyor. Kendilerinden daha iyi bir insanı hazmedemiyor ve bunu çok rahatça dışarı vurabiliyorlar."

K25: "Fakat tüm bunlara rağmen ayn cinsiyette olmanın ve kurulan duygusal bağların bir noktadan sonra yerini despotluk, gerginlik, kıskançlık gibi duygular alıyor."

K30: “Erkek yöneticilerin kadınlarla, kadın yöneticilerin erkeklerle daha rahat çalıştı̆̆ını söyleyebilirim. Bunun birçok nedeni olabilir ama belirgin olarak kadın yöneticiler kendinden herhangi bir konuda iyi olan başka bir kadını etrafında pek istemiyor."

Kadın yöneticilerin duygularıyla hareket etmeleri kodu altında sınıflandırılan katılımcı ifadelerine bakıldığında, bu konuda genel olarak tutarsız davranışlar sergilemeleri ve duygu durumlarının dengesiz olması (Katılımcı 34), ruh hallerinin değişken olması (Katılımcı 10), özel yaşamındaki sorunları işyerine taşımaları ve personele yansıtmaları (Katılımcı 1, 3, 8, 15, 16, 17, 25 ve 30) gibi konulara sıkça değinildiği dikkat çekmektedir. Bu ifadelerden bazıları şunlardır:

K15: "Ne yazık ki zaman zaman kadın yöneticiler özel hayatlarındaki sorunları evde bırakmak yerine iş yerine taşıyabiliyor. Bu da yapılacak işin gecikmesine, onlardaki psikolojik çöküklüğ̈̈n ofise / ekibe yansimasina neden olabiliyor." 
K17: "Evde ya da dışarıda yaşadıkları sorun tamamen ofisin içinde oluyor. Günaydın bile demedikleri olurdu..."

K30: "Ya çok samimi ya da mesafeli oluyorlar. Dengeyi kurma konusunda daha zayıf olduklarımı söyleyebilirim."

Bunların yanı sıra katılımcılar, kadın yöneticilerin iş ile ilgili kararlar verirken de duygularının etkisinde kalabildiklerini ve kimi zaman objektif olamadıklarını dile getirmişlerdir. Örneğin Katılımcı 2 düşüncesini, “özellikle sevdiği bir eleman değilseniz, iş yükünüz her zaman diğer arkadaşlarınızdan daha fazla olur." biçiminde ifade etmiş ve kadın yöneticinin bazen duyguları doğrultusunda hareket ederek astları arasında adaletli davranmadığını vurgulamıştır. Benzer şekilde, aşağıdaki katılımcı ifadeleri de kadın yöneticilerin duygularını iş yerine ve profesyonel kararlarına yansıtmaları ile ilgili algılamalara örnek gösterilebilir:

K13: "Fazla duygusal algıları olduğu için profesyonel olarak gerek karar verme gerekse inisiyatif alma konusunda ikilemde kaldıklarına tanık oldum."

K28: "Kadın yöneticilerin erkek yöneticilere göre yönetim tarzı daha duygu ă̆ırlıklı olduğu için kararları subjektif olabilmektedir."

K34: “Kadın yöneticiler ise duyguların işlerine karıştırmamakta zorlandıkları için bir olayda çok başarılı tutum sergileyebiliyorken başka bir olayda şaşkınlık yaratabiliyorlar."

Tablo 8. Kadın Yöneticilerin Olumsuz Özellikleri

\begin{tabular}{|llccc|}
\hline KATEGORİLER & $\begin{array}{c}\text { KOD } \\
\text { FREKANSI }\end{array}$ & $\begin{array}{c}\text { KATILIMCI } \\
\text { FREKANSI }\end{array}$ & $\begin{array}{c}\text { KATILIMCI } \\
\text { YÜZDESİ }\end{array}$ \\
\hline 1 & Profesyonel Olmayan Davranışlar & 49 & 23 & 57.5 \\
2 & Detayc1 & 14 & 12 & 30.0 \\
3 & Hirsl, Mükemmeliyetçi & 8 & 6 & 15.0 \\
4 & Kuralc1 & 5 & 3 & 7.50 \\
5 & Otokratik & 8 & 6 & 15.0 \\
6 & Yüksek Performans Beklentisi & 4 & 2 & 5.0 \\
& Toplam & $\mathbf{8 8}$ & & \\
\hline
\end{tabular}

Kadın yöneticilerin olumsuz özellikleri kategorisi altında toplanan diğer kodlara bakıldığında, kadın yöneticilerin daha "detaycı" olmalarının 12 katılımcı tarafından 14 kez; "hırslı ve mükemmeliyetçi olma" ile "otokratik olmanın" 8'er kez; "kuralcı olmanın" 5, "yüksek performans beklentisinin" 4 kez dile getirildiği görülmektedir. Detaycı olma konusunda en fazla vurgulanan unsur, kadın yöneticilerin çok detaylı düşünmeleridir. Bu özellik, Tablo 7'de görüldüğü gibi bazen olumlu bir özellik olarak algilanırken bazen de olumsuz olarak algılanabilmektedir. Örneğin Katılımc1 12, "Bazı durumlarda detaylar arasında fazla oyalanmak zaman kaybettirebiliyor, ancak bazı durumlarda ise detaylar belirleyici olabiliyor." diyerek bu özelliğin hem olumlu hem de olumsuz sonuçlarından söz etmiştir. Katılımcı ifadelerinde, kadın yöneticilerin bazen gereksiz detaylara takılıp kalmaları eleştirilmiş (Katılımcı 22, 30) ve bunun kimi zaman yorucu olabildiği (Katılımcı 24); özellikle de bu detaycılık, hırs ve mükemmeliyetçilikten kaynaklandığında çalışanlar üzerinde ilave bir baskıya neden olduğu vurgulanmıştır (Katılımc1 3, 10, 14, 26). Katılımcı 30'un "Bazen gereksiz detaylara takılabiliyor. Bunun çok da gerekli olmadığını anlattı̆̆ımızda bunu anlasa bile onay vermez; 'Ben öyle istiyorum' der." (...) Hep kendi istediği olsun istiyorlar. Önerilerim sanki mevcut durumu beğgenmeme gibi algılanıyor." şeklinde dile getirdiği görüşü, kadın yöneticilerin detaycılığının yanında "Otokratik Olma" özelliklerine de işaret etmektedir. Zira burada, yöneticinin astların görüşlerine değer vermediği ve tüm karar verme yetkisini kendisinde topladığı fikri uyanmaktadır. Aşağıda verilen diğer iki ifadede de benzer bir katılığa ve kontrolcü tutuma rastlanmaktadir:

K1: "Personeline doğru gelen ve personelin doğruluğundan emin olduğu bir konu hakkında inatla yanlış olduğunu savunmaktadır ve bilerek onu yanlışa yönlendirmektedir."

K16: "Kadın yöneticiler işe odaklanmalarının dışında çevresel etkenleri, insanları da kontrol altında ve gözlemleri dahilinde tutmaya daha meyilli oluyorlar."

Kadın yöneticilerin "Kuralcı Olma" kategorisinde değerlendirilen özelliklerine ilişkin katılımcı ifadeleri incelendiğinde, bu ifadelerde kadın yöneticilerin inisiyatif almaktan kaçındıkları ve kurallara, standartlara, 
prosedürlere harfiyen uyulmasını talep ettikleri görülmektedir. Özellikle kadın yöneticilerle 20 yıl çalışmış olan bir sınıf öğretmeninin (Katılımcı 27), "Dezavantajlarının başında çok kuralcı olmaları geliyor. İş konusunda alınan kararların tamamıyla uygulanmasını istiyorlar. Aksaklık çıması paniklemelerine neden oluyor." (...) "Erkek yöneticiler olumsuz durumu kendi çözmek için uğraşıyor fakat kadın yönetici kuralı neyse, yaptırımı ne ise onun uygulanmasını istiyor." biçimindeki ifadesi, söz konusu durumu net bir biçimde özetlemektedir. Benzer şekilde İş ve Meslek Danışmanı olan Katılımcı 11, "Farkın temel sebebi bence kadın yöneticilerin kuralcı ve esnemeyen, belli kalılar içinde hareket etmeyi tercih eden yönetsel anlayışı." (...) "İ̧̧ konusunda risk almazlar, inisiyatif kullanmaktan kaçınırlar." demiştir.

\subsection{Kadın Yönetici ile Çalışmanın Avantaj ve Dezavantajlarına İlişkin Bulgular}

Kadın yönetici ile çalışmanın avantajlarına ilişkin katılımcı ifadelerinin kodlanması ile altı temel kategori ortaya çıkmıştır (Tablo 9). Bunlar; (i) Kadın ve anne olması ile ilgili avantajlar, (ii) Olumlu bir iş yeri atmosferi yaratma, (iii) Pratik ve hızlı sorun çözme (iv) Mentorluk yapma (v) İşleri planlanan zamanda tamamlama ve (vi) İyi bir dinleyici olmadır. Bu kategorilere toplam 91 kez değinildiği saptanmıştır. Diğer taraftan, avantajlar konusunda 33 katılımcının ifadeleri ile kodlama yapılmıştır. Zira 6 katılımcı (Katılımcı 8, 9, 10, 11, 29 ve 39) avantaj ile ilgili soruya doğrudan "kadın yönetici ile çalı̧manın bir avantajını görmedim" cevabını vermişlerdir.

Tablo 9. Kadın Yönetici ile Çalışmanın Avantajları

\begin{tabular}{|llccc|}
\hline & KATEGORİLER & $\begin{array}{c}\text { KOD } \\
\text { FREKANSI }\end{array}$ & $\begin{array}{c}\text { KATILIMCI } \\
\text { FREKANSI }\end{array}$ & $\begin{array}{c}\text { KATILIMCI } \\
\text { YÜZDESI }\end{array}$ \\
\hline 1 & Kadın ve Anne Olmaları ile ilgili Avantajlar & 67 & 31 & 77,5 \\
2 & İyi Bir Dinleyici Olma & 3 & 3 & 7,5 \\
3 & Olumlu Bir İşyeri Atmosferi Yaratma & 9 & 5 & 12,5 \\
4 & İşleri Planlanan Zamanda Tamamlama & 3 & 1 & 2,5 \\
5 & Pratik ve Hızlı Sorun Çözme & 5 & 3 & 7,5 \\
6 & Mentorluk Yapma & 4 & 1 & 2,5 \\
& Toplam & $\mathbf{9 1}$ & & \\
\hline
\end{tabular}

"Kadın ve anne olması ile ilgili avantajlar" kategorisine 31 katılımc tarafından (katılımcların \%78'i) toplam 67 kez değinilmiştir. Bu kategori içerisinde üç alt kod ortaya çıkmıştır. Bunlar: "empati ve rahatlık", "sıcak ve samimi ilişkiler" ile "cinsel tacize maruz kalmama" avantajıdır. Empati ve rahatlik koduna katılımcılar toplam 45 kez değinmişlerdir. Bu başlık altında örneğin beş katılımcı $(12,18,19,23,38)$, doğrudan "Kadının halinden, en iyi kadın anlar" cümlesini kurarak düşüncelerini özetlemişlerdir. Aynı cinsten olmanın bir başka avantajı olarak katılımcılar, kadın yöneticilere çok özel ve hassas durumlarını rahatlıkla anlatabildiklerinden bahsetmişlerdir. Örneğin Katılımc1 2, "Hemcinsinize rahat açıklama yapabildiğiniz için doktora gidebilmek için izin almak daha kolaydır." derken Katılımcı 4, "Kadınla çalı̧mak, sorunları iletme yönünden daha rahattır. Erkeklere kadınsal sorunları anlatmak daha bir güçtür." demiştir. Katılımcı 15 ise bu konudaki düşüncelerini, "Kadınsal ve zaman zaman erkeklerin anlayamayacă̆ı konular söz konusu olduğunda kadın bir yöneticiye sahip olmak ve her konuda daha şeffaf olabilmek bir avantaj." biçiminde ifade etmiştir.

Bazı katılımcılar ise "Annelik" olgusuna dikkat çekmişler ve özellikle kadın yöneticinin "anne" olması durumunda, astlarını çok daha iyi anlayıp onlara esneklik sunabilmesini vurgulamışlardır. Aşağıdaki örneklerden de görüleceği üzere, bu konu ile ilgili görüşler, benzerlik göstermektedir.

K6: "Ev, aile, çocuk gibi iş dışındaki yaşamınızda gelişebilen sorunlara karşı daha duyarlı ve anlayışlı olabiliyorlar."

K20: “Özellikle bir anneyse, çocuğunuz hastalandı̆̆ında izin konusunda daha iyimser yaklaşırlar.”

K22: "Kadınların çocuklar konusunda daha hassas, erkeklerin daha gaddar olduğunu gördüm. O nedenle kadın yöneticiler çocukla ilgili bir problem olduğunda daha fazla empati kurabiliyorlar."

Yöneticinin kadın ve anne olması ile ilgili avantajlardan bir diğeri, "sıcak ve samimi ilişkiler" başlı̆̆ı altında sınıflandırılmış olup bu konuya katılımcılar tarafından 20 kez değinilmiştir. Bu konuda özellikle Katılımcı 30'un, "(Kadın yönetici ile) biçimsel olmayan ilişkiler kurmak daha kolay. Erkek yöneticilerle kurulan bu tarz ilişkiler farklı yorumlanabiliyor." cümleleri dikkat çekici olup iş yaşamında dahi toplumsal bakış açısı nedeniyle kadınerkek ilişkilerinde daha dikkatli davranılmaya çalışıldığını göstermektedir. İki katılımcı ise kadın yönetici ile 
çalışmanın avantajlarından birinin "Cinsel tacize maruz kalmamak" olduğunu ifade ederek bu konuyu daha hassas bir noktaya taşımışlardır. Reklamcılık alanında üst düzey yönetici olan Katılımcı 25 bu konudaki düşüncesini, "Özellikle Türkiye'de erkek yöneticilerin taciz mobbingi düşünüldü̈̆̈̈̈nde kadın yönetici çok avantajlı oluyor." şeklinde dile getirmiştir. Katılımcı 34 ise, kadın yönetici ile çalışırken fiziksel zorbalı̆̆a veya cinsel istismara maruz kalınmamasını bir avantaj olarak belirtmiştir.

Kadın yönetici ile çalışmanın avantajları içerisinde en sık tekrarlanan ikinci kategori "Olumlu bir iş yeri atmosferi yaratma" dır. Bu kategoriye 5 katılımcı tarafından 9 kez değinilmiştir. Konu ile ilgili öne çıkan ifadeler incelendiğinde, kadın yöneticilerin çeşitli tutum ve davranışları ile işyerinde katılımcı, demokratik, dengeli, kapsayıcı, adil, güvenli, huzurlu ve anlayışı bir ortam yarattıkları sonucuna ulaşılmaktadır. Bunlara ilave olarak, kadın yöneticilerin astlarına anne/abla gibi yaklaşabilmeleri, sevgilerini açıkça gösterebilmeleri, onların özel günlerine önem vermelerinin, çalışanların kendilerini aile ortamında hissetmelerine yardımcı olduğu görülmektedir. Bu konuyla ilgili bazı katılımcı ifadeleri aşağıda sunulmaktadır:

K14: “Daha anlayışlı ve hoşgörülüler. Empati kurabiliyorlar ki bu da zaten zor olan ve zamanımızın büyük çoğunluğunu geçirdiğimiz çalışma ortamında ihtiyaç duyduğumuz insani tarafı güçlendiriyor, aile ortamını yaratıyor." (...) "Grup içi iletişimi güçlendiriyor ve sıklı̆̆ın artırarak daha katılımoı ve demokratik bir ortam yaratıyorlar." (...) "Her seviyede, her çalışana değer verdiklerini gösterebiliyorlar. Dengeli, kapsayıcı ve adil bir çalışma ortamı yaratıyorlar."

K28: “Çalışanlarını, çocukları olarak görüp her türlü iş-özel sorunlarına karşı ilgili yaklaşımları, çözüm bulmaya çalışmaları, anaç tutumları sebebiyle gördüğüm sevgi, beni her zaman aile ortamında hissettirmiştir."

Kadın yönetici ile çalışmanın dezavantajları kapsamında ise iki temel kategori ortaya çıkmıştır (Tablo 10). Bunlar, (i) Duyguların iletişim ve karar süreçlerini bozması ve (ii) Sınırların aşılması ve mesafeyi koruyamama olarak isimlendirilmiştir. Bu kategoriler içerisinde 6 katılımcı 10 kez, kadın yönetici ile ilişkide sınırların aşılması ve aradaki mesafenin korunamaması sorununu dile getirmiştir. Bu konu ile ilgili olarak katılımcılar, kadın yönetici ile samimiyetin fazla olmasının dezavantajlı olabildiğinden, aradaki saygının zarar görmesinden veya bir araya gelindiğinde iş yerinde olanlar hakkında dedikodu yapılmasından bahsetmişlerdir. Burada kadın yöneticiye yöneltilmiş bir eleştiriden ziyade, iki tarafın da ilişkinin sınırını çizememesine yönelik bir özeleştiriden söz etmek mümkündür.

K5: "Dezavantaj ise; bazen bu samimiyet bazı zamanlar sayginin zedelenmesine de neden olabiliyor. Sınırları aşmak veya aştığın fark etmemek bu samimiyet yüzünden mümkün olabiliyor."

K22: "Bence en büyük dezavantajı, bir kadınla bir masaya oturduğunuzda, konunun eninde sonunda şirkette olup bitenlere, kimin kiminle ne yaptığına bağlanması."

Diğer taraftan, aşağıdaki iki katılımcının ifadesinde görüleceği üzere, bazen bu konuda doğrudan kadın yöneticiyi hedef alan eleştiriler de söz konusu olabilmektedir:

K30: "Özel hayatınızla daha fazla ilgileniyorlar ve mesafe koymak istediğinizde bundan hoşlanmıyorlar."

K40: “Kadın yönetici, personelle mesafesini koruyamıyor. İş dışı konuşmalara yer veriyor. Gruplaşmalara sebebiyet veriyor. İşle ilgisi olmayan, duygusal davranışlar sergiliyor. Görüntüye, kurumsal görünümden fazla yorum yapıyor (saç, tırnak)." (...) "Kadın yönetici için (dezavantajlar), gereğinden fazla özel hayata müdahale edilmesi, gruplaşma yaratılması, dedikodu ve çekiştirmeye yol açılması, sürekli ilgi beklentisi, gereksiz konuşmalardır."

Tablo 10. Kadın Yönetici ile Çalışmanın Dezavantajları

\begin{tabular}{|llccc|}
\hline KATEGORILER & $\begin{array}{c}\text { KOD } \\
\text { FREKANSI }\end{array}$ & $\begin{array}{c}\text { KATILIMCI } \\
\text { FREKANSI }\end{array}$ & $\begin{array}{c}\text { KATILIMCI } \\
\text { YÜZDESİ }\end{array}$ \\
\hline 1 & Duyguların, İletişim ve Karar Süreçlerini Bozması & 19 & 14 & 35,0 \\
2 & Sinırların Aşlması - Mesafeyi Koruyamama & 10 & 6 & 15,0 \\
& Toplam & $\mathbf{2 9}$ & & \\
\hline
\end{tabular}

Kadın yöneticilerin erkek yöneticilere kıyasla daha duygusal olmaları, kimi zaman olumlu bir özellik olarak değerlendirilirken bazen de olumsuz olarak algılanabilmektedir. Özellikle bu duygusallığın kadın yöneticinin 
davranışlarına ve astları ilgilendiren kararlara çok fazla yansıması durumunda katılımcılar bunu bir dezavantaj olarak görmeye başlamaktadır. Bu konuya 14 katılımcı toplam 19 kez temas etmiştir.

K6: "Kendini size rakip olarak gördüğünde iletişim süreci bozulabiliyor ve mobbinge gidebilen bir süreç başlıyor. Bazı durumlarda duyguları mantığının önüne geçebiliyor. Kişiler arası iletişimde daha önce yaşanılan problemler her iki taraf açısından unutulmadığı için sonraki iletişim ve karar verme süreci olumsuz etkilenebiliyor."

K13: "Fazla duygusal algıları olduğu için profesyonel olarak gerek karar verme gerekse inisiyatif alma konusunda ikilemde kaldıklarına tanık oldum. Bu nedenle çalş̧an olarak eğer siz de duygusalsanız ve sorunlarla başa çıkamama durumunuz varsa çatışma yaşıyorsunuz."

K17: “Erkek yöneticilerin de bizleri anlamadığı birçok şey olabiliyor fakat daha alttan alan yapıları var. Bir hata yaptıklarında özür dilemeseler bile bir şekilde kendilerini affettirmeye çalışıyorlar. Kadınlarda ise asla geri dönüş olmuyor."

Yukarıdaki ifadelerden de anlaşılacağı üzere, iş yerindeki ast-üst ilişkilerinde kadınlar arasındaki çatışmaların çözümü, bir kadın çalışan ile erkek yönetici arasındaki çatışmaya kıyasla, çok daha zor olabilmektedir. Kadın yöneticilerle ilişkilerde yaşanabilecek olumsuz bir durum, yöneticinin iletişimi bazen tamamen kesmesi ile sonuçlanmakta ve bu da ilişkinin yeniden tesis edilmesini imkansız hale getirebilmektedir.

\subsection{Kadın veya Erkek Yönetici ile Çalışma Tercihlerine İlişkin Bulgular}

Katılımcılara yöneltilen “Özel olarak Kadın ya da Erkek yönetici ile çalışmayı tercih eder misiniz?" sorusuna katılımcıların \%37,5'i (15 katılımcı) "Erkek Yönetici", \%17,5'i (7 katılımcı) "Kadın yönetici" cevabını vermişlerdir (Tablo 11). Buna ilave olarak 5 katılımcl, çeşitli nedenlerle (örneğin hiç erkek yönetici ile çalışmamış olması gibi) herhangi bir tercihte bulunamayacağını ifade ederken 5 katılımcı da yöneticileri kadın ya da erkek olarak ayırt etmek istemediğini; bu tür bir tercihte cinsiyetin değil, yöneticinin adil, karakterli, profesyonel olması gibi özelliklerinin belirleyici olması gerektiğini ifade etmiştir.

Tablo 11. Kadın ya da Erkek Yönetici ile Çalışma Tercihleri

\begin{tabular}{|llcc|}
\hline & KATEGORILER & KATILIMCI FREKANSI & KATILIMCI YÜZDESİ \\
\hline 1 & Erkek yönetici tercih ederim & 15 & 37.5 \\
2 & Kadın yönetici tercih ederim & 7 & 17.5 \\
3 & Yöneticinin özelliklerine bağlı & 5 & 12.5 \\
4 & Tercih yapamam & 5 & 12.5 \\
\end{tabular}

Katılımcı 19'un "Tercih etme hakkım olsaydı kesinlikle kadın yönetici ile çalısmak isterdim." cümlesine karşılık, Katılımcı 22'nin "Tercih şansım olsa kesinlikle erkek yönetici ile çalışmayı tercih ederim." cümleleri göz önüne alındığında, yine geniş bir skalada değerlendirilebilecek cevaplar olduğu söylenebilir. Bu noktada, yöneticinin özelliklerinin ön planda olmasının daha doğru olacağını belirten katılımcıların ifadelerinden örnekler sunularak bu katılımcıların hangi faktörleri vurguladıkları incelenebilir.

K16: "Günümüzde artık erkek-kadın yönetici olarak ayırmak biraz daha zorlaşıyor. Cinsiyet ayrımı gözetmeksizin insani ve profesyonel dengeyi kurabilen bir yönetici tercih ediyorum."

K23: "Ben herhangi bir cinsiyeti özel olarak tercih etmem. Önemli olan idareci vasıflarma sahip olabilmek. Bu da karakter ile ilgili bence."

K26: "Profesyonel ve adaletli olduktan sonra fark etmez kadın ya da erkek olması."

K38: "Yöneticinin cinsiyetinden ziyade insanlı̆̆ ve adaleti önemli bence."

K29: "Özel olarak hangisiyle çalısmak isterdim diye düşündüğümde bir tercihte bulunamıyorum ve aslında tercihte bulunulmasının çok da doğru olduğunu düşünmüyorum."

\section{SONUÇ VE TARTIŞMA}

Kadın çalışanların kadın yöneticileri hakkındaki algılamalarını ve tutumlarını araştırmayı ve iş yaşamında kadınlar arasındaki hiyerarşik ilişkileri, literatürdeki mevcut yaklaşımlar ışığında tartışmayı amaçlayan bu 
çalışmada 20 farklı sektörden 40 kadın çalışana ulaşılarak nitel bir araştırma gerçekleştirilmiştir. Elde edilen veriler içerik analizine tabi tutulmuş ve aşağıda kısaca özetlenen temel sonuçlara ulaşılmıştır:

- Katılımcıların yaklaşık yarısı kadın yönetici ile çalışmanın kendisinde olumlu duygular uyandırdığını söylerken diğer yarısı olumsuz duygular uyandırdığını ifade etmiştir. Bu bulgu, literatürdeki araştırmalar ile birlikte değerlendirildiğinde çalışanların kadın yöneticiyle çalışmak konusundaki tutumları hakkında net bir sonuç çıkarmak mümkün görünmemektedir. Zira bazı araştırmalarda katılımcıların "kadın yönetici" fikrine olumsuz yaklaştıkları (Balgiu, 2013) ya da başarılı bir yöneticinin "erkek" olarak düşünüldügü (Willemsen, 2002) sonucuna ulaşılırken Sertkaya ve arkadaşlarının (2013) spor örgütlerinde yaptıkları araştırmada olduğu gibi, kadınların, hemcinslerinin yönetici olmalarına erkeklere kıyasla daha olumlu yaklaştıklarının tespit edildiği çalışmalar da bulunmaktadır.

- Katılımcıların yarısından fazlası, kadın ve erkek yönetici ile çalışmak arasında belirgin farklar olduğu yanıtını vermişlerdir.

- Erkek yöneticilerin kadın yöneticilere kıyasla daha profesyonel davranışlar sergiledikleri, bu çerçevede, karşılıklı ilişkilerde daha mesafeli oldukları, sınırları aşmadıkları, duygularını işe karıştırmadıkları, net kararlar verebildikleri, kıskanç ve kaprisli olmadıkları, astlarını kendilerine rakip olarak görmedikleri, onlara özel hayatlarıyla ilgili sorular sormadıkları vurgulanmıştır. Diğer taraftan, erkek yöneticiyle çalışmanın olumsuz bir yönü olarak, kadın çalışanların özel durumlarını erkek yönetici ile konuşmakta zorlanmaları ve rahat iletişim kuramamaları belirtilmiştir. Ayrıca erkek yöneticilerin duygudan uzak ve görev odaklı bir iletişim tarzını benimsemeleri de olumsuz bir özellik olarak tanımlanmış ve duygusal zekalarının ve empati yeteneklerinin kadın yöneticilere kıyasla daha zayıf olduğu vurgulanmıştır.

- Kadın çalışanların özellikle aile yaşamlarına ilişkin sorumlulukları ve kadınlara özgü rahatsızlıklar söz konusu olduğunda, kadın astlar kadın yöneticilerle birlikte çalışmayı önemli bir avantaj olarak görmektedirler. Bu durum, toplum tarafından kadınlara atfedilen cinsiyet rollerinin bir sonucu olarak değerlendirilebilir. Bunun yanı sıra, kadın yöneticilerin detaylı ve çok yönlü düşünebilme, şefkatli, düzenli, disiplinli, duygusal, nazik, iyi bir iletişimci olma gibi özellikleri, katılımcılar tarafından sıklıkla vurgulanmıştır.

- Kadın yöneticilerin olumsuz özelliklerinin başında profesyonel olmayan davranışlar kategorisi gelmektedir. Bu kategori, kıskanç ve rekabetçi olma, duygularıyla hareket etme, yüksek ego, sert ve agresif olma, hemcinslerinin dış görünüşü ve özel hayatı hakkında konuşmak gibi davranışları içermektedir. Kadın yöneticilerin diğer olumsuz özellikleri ise detaycı, hırslı, mükemmeliyetçi, otokratik ve kuralcı olmalarıdır. Kadın yöneticilerin olumsuz özelliklerine ilişkin bu bulguların, İmamoğlu Akman ve Akman'ın (2016) kadın öğretmenlerin kadın okul yöneticileri hakkındaki görüşleri ile ilgili araştırmalarının sonuçları ile önemli ölçüde benzerlik taşımaktadır.

- Kadın yönetici ile çalışmanın, kadın ve anne olması, olumlu bir iş yeri atmosferi yaratma, pratik ve hızlı sorun çözme, mentorluk yapma, işleri planlanan zamanda tamamlama ve iyi bir dinleyici olma gibi altı temel avantajı ortaya çıkmıştır.

- Katılımcılar, kadın yönetici ile samimiyetin fazla olmasının bazen dezavantajlı olabildiğinden bahsetmiş ve bunun iş ilişkisine zarar verebildiğini vurgulamışlardır. Bu noktada, doğruda kadın yöneticiye yöneltilmiş bir eleştiriden ziyade, iki tarafın da ilişkinin sınırını çizememesine yönelik bir öz-eleştiriden söz etmek mümkündür. Bununla birlikte, kadın yöneticinin bazı davranışlarının katılımcılar tarafından özel hayata müdahale olarak algılandığına ilişkin ifadeler de bulunmaktadır.

- Katılımcıların yaklaşık yüzde 40'ı erkek yöneticiyle; dörtte birinden daha azı ise kadın yöneticiyle çalışmayı tercih ettiğini belirtmiştir. Bu bulgunun geçmişteki ve günümüzdeki farklı araştırma sonuçları ile tutarlı olduğu görülmektedir (örneğin Kanter, 1993; Berkman, 2005; Eagly ve Karau, 2002; Randstad Araştırması, 2016; www.kigem.com, 2019). Bu durum, gerek toplumda ve doğal olarak kadın çalışanlarda varlığını sürdürmeye devam eden cinsiyetçi rol kalıplarına ve gerekse kadın yöneticilerin bir kısmının, Sosyal Kimlik Teorisi ve Kraliçe Arı fenomeni bağlamında değerlendirilebilecek tutumlarına dayandırılabilir.

Kadın çalışanların kadın yöneticilere ilişkin algılamaları değerlendirildiğinde, Türk yönetim kültürünün bir özelliği olan "dişil yönetim" tarzına ilişkin beklentinin devam ettiği söylenebilir. Nitekim araştırmada, kadın yöneticilerin nazik, uyumlu, anlayışlı, yardımsever, dengeli olmak gibi dişil özellikler sergilemeleri katılımcılar tarafından "olumlu" olarak değerlendirilirken hırslı, mükemmeliyetçi, detaycı, kuralcı, otokratik ve iş odaklı olma gibi eril davranışlar sergilemeleri "olumsuz" olarak nitelendirilmiştir. Bu bulgu, Özen'in (1998) “Türkiye’ de Kadın ve Erkek Kamu Yöneticilerinin Yönetim Tarzı Açısından Farklılaşması ve Eril Erkek 
- Dişil Kadın Varsayımının Geçerliliği” isimli çalışmasının sonuçları ile tutarlıdır. Bununla birlikte, adı geçen araştırmada her iki grubun da dişil bir yönetim tarzı benimsediği; ancak kadın yöneticilerin göreceli olarak biraz daha dişil göründükleri saptanmıştır. Görüldüğü gibi, kadın yöneticilerden beklenen bu davranışlar, Türk toplumunda kadına ve erkeğe atfedilen cinsiyet rolleriyle ilişkilidir. Doğal olarak iş yaşamında da bu cinsiyet rolü beklentileri devam etmekte ve bu kalıpların dışında davranan kadın yöneticiler yadırganmakta ve eleştirilmektedir.

Yönetimde kadın-erkek farklılaşması perspektifine uygun olarak, kadın yöneticilerden bazen yöneticilikten ziyade "annelik" yapmaları beklenmekte; gerçekte erkek bir yöneticiden beklenmeyecek derecede şefkat, anlayış ve hoşgörü talep edilebilmektedir. Bunu yapmayan bir kadın yönetici ise erkeksi olmakla, kadın kimliğini yitirmekle, anlayışsız olmakla suçlanabilmektedir. Nitekim mevcut araştırmada dikkat çeken bir nokta, katılımcıların kadın yöneticilerden yüksek düzeyde profesyonellik beklerken aynı zamanda kendisini bir anne ve kadın olarak her zaman anlamasını, empati kurmasını ve kendisine şefkatle yaklaşmasını beklemeleridir. Bu durum, Türk iş insanlarının "paternalist liderlik" beklentisine dayandırılabilir. Paternalist liderliğin kökenleri Türk yönetim tarihi kadar eski olup son yıllarda Türkiye'de yapılan araştırmalar, üniversite öğrencilerinin ve çalışanların yöneticilerinden paternalist liderlik davranışları beklemeyi sürdürdügünü göstermiştir (Aktaş ve Sargut, 2011; Gürcan, 2018; Gelmez ve Akça Ertürk, 2019; Tolay, 2020). Ancak bu beklentinin, kadına yönelik cinsiyetçi önyargılar ile birleştiğinde, kadın yöneticiden beklenen rolleri daha da karmaşıklaştırdığı söylenebilir.

Diğer taraftan, çalışmanın kapsamını sınırlandırma gereği nedeniyle bu araştırmaya dahil edilmeyen "katılımcı öyküleri" ile birlikte düşünüldüğünde, bazı kadın yöneticilerin kadın astlarına yönelik davranışlarının, hukuki bir süreç başlatıldığında ciddi yaptırımlara neden olabilecek düzeyde mobbing davranışları içerdiği görülmüştür. Kadın yöneticilerin erkeklerin egemen olduğu iş yaşamında üst düzeylere tırmanmak ve o düzeylerde başarılı bir biçimde kalmak gibi bir güdüyle erkeklerden daha eril eğilimler yansıtması "Yönetimde kadın-erkek benzeşmesi" perspektifinden değerlendirilebilir. Kadın yöneticilerin kadın astlarına yönelik saldırgan tutumlarını ise "Kraliçe Arı Fenomeni" çerçevesinde düşünmek mümkündür. Bu açıdan bakıldığında, mevcut araştırmanın hem yönetimde kadın-erkek farklılaşması hem de kadın-erkek benzeşmesi yaklaşımlarını desteklediği görülmüştür. Diğer taraftan, Özen'in (1998) araştırmasında ortaya çıkan bir sonuç, Türk kültürü ve kamu-özel sektörleri açısından değerlendirildiğinde oldukça çarpıcıdır. Araştırmada, kadın yöneticilerin erkeklerin egemen olduğu bürokratik yapı içinde üst kademelere tırmanmak ve o kademelerde başarılı bir biçimde kalmak güdüsüyle daha eril ya da daha az dişil eğilimler yansıtmadığı saptanmıştır. Bu sonuç, yönetimde kadın-erkek benzeşmesi yaklaşımını desteklememektedir. Fakat yazar bu sonucu, kamu kurumlarındaki, performansa değil kıdeme ve kayırmacılığa dayalı yükselme sistemi ile ilişkilendirmiştir. Buna göre, benzer bir araştırmanın, performansa dayalı ödüllendirmenin ve yükselmenin esas olduğu özel sektörde yapılması durumunda, farklı sonuçlar elde edilmesi beklenebilir. Bu bakımdan konu ile ilgilenen araştırmacılara, Türkiye'de kamu sektörü ve özel sektör arasındaki ayırt edici farklılıkları göz önünde tutarak her iki sektör için ayrı ayrı ve karşılaştırmaya dayalı araştırmalar yapmaları önerilebilir.

$\mathrm{Bu}$ çalışmanın, kadın çalışanların perspektifinden kadın yöneticilerin nasıl algılandığını göstermesi bakımından kadın yöneticilerimize bir bakış açısı kazandırabileceği düşünülmektedir. Gerek sayısallaştırılmış verilerle gerekse katılımcı ifadelerinden örneklerle, kadın çalışanların bir kadın yöneticide ne tür davranışları beğendikleri, hangi davranışları eleştirdikleri veya rahatsız oldukları gibi sorulara somut ve derinlemesine yanıtlar verilebilmiştir. Kadın çalışanlar açısından ise bu çalışmanın önemli bir yararı, yapılan değerlendirmelerin bireysel algılamalara göre farklılaşabildiğini göstermesidir. Örneğin, kadın yöneticilerin detaylı ve çok yönlü düşünme becerisi bazı katılımcılar tarafından çok önemli bir yetenek olarak görülürken bazı katılımcılar tarafından rahatsız edici ve yıpratıcı olarak değerlendirilmiştir. Bunun da ötesinde, kadın çalışanlar, genellikle kadın yöneticileri duygusal olmaları, duygularıyla hareket etmeleri ve bu nedenle de profesyonel olmadıkları yönünde eleştirirken diğer taraftan kadın ve anne oldukları için rahat iletişim kurmanın avantajlarından bahsetmekte ve kendilerine bu konuda her zaman anlayış göstermelerini beklemektedirler. Hurst ve arkadaşlarının (2018a) çalışması ile tutarlı olan bu sonucun, bir kez daha kadına atfedilen cinsiyet rolleri ile yakından ilişkili olduğu görülmektedir. Bu bağlamda, kadın çalışanların, kadın yöneticileri değerlendirirken cinsiyetten bağımsız olarak değerlendirmelerinin önemli olduğu söylenebilir. 
Araştırmanın sonuçları, kadın çalışanların erkek yöneticilerle çalışmayı tercih etme eğiliminin, literatür ile tutarlı olarak devam ettiğini de kanıtlamaktadır. Bununla birlikte, katılımcıların bu tercihinde kendi olumsuz deneyimlerinin belirleyici olduğu ve kadın yöneticileri genellikle cinsiyetten bağımsız faktörlerle değerlendirmeye çalıştıkları da gözlemlenmiştir. Çalışmanın genel olarak Yönetim ve Organizasyon literatürüne, özel olarak ise Kadın Yöneticiler, Cinsiyet Çalışmaları ve Cinsiyetçi Kalıp Yargılar ile ilgili alanlara katkı sağlaması umulmaktadır. Konu ile ilgilenen araştırmacılara, kadın yöneticilerin bakış açısını açığa çıkarmaya yönelik nitel araştırmalar yaparak literatüre katkı sağlamaları önerilebilir.

\section{TEŞEKKÜR}

Uzman incelemesini gerçekleştiren Sayın Doç. Dr. Burcu Şentürk (Ege Üniversitesi, İİBF, İşletme Bölümü), Doç. Dr. Olca Sürgevil Dalkılıç (Dokuz Eylül Üniversitesi, İ̈BF, İşletme Bölümü), Öğr. Gör. Dr. Benan Kurt Yılmaz (Sinop Üniversitesi, Ayancık Meslek Yüksekokulu) ve Araş. Gör. Umut Denizli’ye (Dokuz Eylül Üniversitesi, İ̈BF, Çalışma Ekonomisi ve Endüstri İlişkileri Bölümü) araştırmaya yaptıkları değerli katkılar için teşekkür ederim.

\section{KAYNAKÇA}

Alemie, A. B. (2011). Perceived Difference Between Male and Female Managers: The Impact of Gender Stereotyping on Leadership Style, Emergence, Effectiveness and Acceptance, LAP LAMBERT Academic Publishing.

Aktaş, M. ve Sargut, A. S. (2011). İzleyicilerin Kültürel Değerlerine Göre Liderliğe Duyulan Gereksinme Nasıl Farklılaşır?: Kuramsal Bir Çerçeve, Amme İdaresi Dergisi, 44(4): 145-163.

American Psychological Association (2006). When the Boss is a Women, https://www.apa.org/ research/action/boss (Erişim Tarihi: 28 Mart 2020).

Ataay, N. A. (1998). Kadın Yöneticilerin Kariyer Boyutları ve Etmenleri, 20. Yüzyılın Sonunda Kadınlar ve Gelecek Konferansı, Türkiye ve Orta Doğu Amme İdaresi Enstitüsü, İnsan Hakları Araştırma ve Derleme Merkezi, Yayın No: 16., Ankara, 237-253.

Akbaş, G. ve Korkmaz, L. (2017). Kadın Yöneticiler: Görünmez Engellerin Gölgesinde Yükselme Çabası, İş ve Insan Dergisi, 4 (2), 73-86.

Aycan, Z. (2004). Key Success Factors for Women in Management in Turkey, Applied Psychology: An International Review, 53 (3), 453-477.

Balgiu, B. A. (2012). Perceptions of Women as Managers. The Difference of Attitude between Employees and Non-Employess, Procedia - Social and Behavioral Sciences, 78, 330-334.

Baykal, E. (2018). Sosyal Kimlik Teorisi Perspektifiyle Kraliçe Arı Sendromu, Karadeniz Teknik Üniversitesi SBE Sosyal Bilimler Dergisi, 8 (16), 159-175.

Berkman, Y. A. (2005). Attitudes Towards Women Managers: Development of a New Measure. Koç Üniversitesi SBE Yüksek Lisans Tezi.

Boulgarides, J. D. (1984). A Comparison of Male and Female Business Managers, Leadership \& Organization Development Journal, 5 (5), 27-31.

Brenner, O. C., Tomkiewicz, J. ve Schein, V. E. (1989). The Relationship Between Sex Role Stereotypes and Requisite Management Characteristics Revisited, The Academy of Management Journal, 32 (3), 662-669.

Bickford, N. (2011). Queen Bees - An Evolving Species or an Office Myth? Financial Times. https://www.ft.com/content/9bc76152-f3f9-11e0-b221-00144feab49a (Erişim Tarihi: 30 Mart 2020).

Burke, S. ve Collins, K. (2001). Gender Differences in Leadership Styles and Management Skills, Women in Management Review, 16 (5), 244-257.

Cevher, E. ve Öztürk, U. C. (2015). İş Yaşamında Kadınların Kadınlara Yaptığı Mobbing Üzerine Bir Araştırma, İnsan ve Toplum Bilimleri Araştırmaları Dergisi, 4 (4), 860-876.

Derks, B., Laar, C. V., Ellemers, N. ve Groot, K. (2011a). Gender-Bias Primes Elicit Queen-Bee Responses among Senior Policewomen, Psychological Science, 22 (10), 1243-1249. 
Derks, B., Ellemers, N., Laar, C. V. ve Groot, K. (2011b). Do Sexist Organizational Cultures Create the Queen Bee, British Journal of Social Psychology, 50, 519-535.

Derks, B., Laar, C. V. ve Ellemers, N. (2016). The Queen Bee Phenomenon: Why Women Leaders Distance Themselves from Women, The Leadership Quarterly, 27, 456-469.

Duehr, E. E. ve Bono, J. E. (2006). Men, Women, and Managers: Are Stereotypes Finally Changing?, Personnel Psychology, 59(4), 815-846.

Eagly, A. H. ve Johnson, B. T. (1990). Gender and Leadership Style: A Meta-Analysis, Psychological Bulletin, 108(2), 233-256.

Eagly, A. H. ve Johannesen-Schmidt, M. C. (2001). The Leadership Styles of Women and Men, Journal of Social Issues, 57 (4), 781-797.

Eagly, A. H. ve Karau, S. J. (2002). Role Congruity Theory of Prejudice Toward Female Leaders, Psychological Review, 109(3), 573-598.

Er, O. ve Adıgüzel, O. (2015). Cam Tavan Gölgesindeki Kraliçe Arılar: Kadınların Kariyer İlerlemelerinde Karşılaştıkları Engeller ve Etkili Liderlik, Recep Tayyip Erdoğan Üniversitesi SBE Dergisi, 2, 163-175.

Gelmez, M. ve Akça Ertürk, E. (2019). Özel Bir Hastanede Liderlik Stillerinin ve Çalışan Performansının İncelenmesine Yönelik Bir Araştırma, Hacettepe Sağlık İdaresi Dergisi, 22 (1), 51-72.

Gmür, M. (2006). The Gendered Stereotype of the 'Good Manager' Sex Role Expectations towards Male and Female Managers, Management Revue, 17 (2), 104-121.

Gürcan, N. (2018). Türk Kültüründe Paternalist Liderlik Davranışlarının İzleyenler Üzerindeki Etkisi: Y Kuşağına Yönelik Bir Araştırma. DEÜ SBE Yüksek Lisans Tezi, İzmir.

Hurst, J., Leberman, S. ve Edwards, M. (2018a). Women Managing Women: An Holistic Relational Approach to Managing Relationships at Work, Journal of Management \& Organization, 24 (4), 500-516.

Hurst, J., leberman, S. ve Edwards, M. (2018b). The Career Impacts of Women Managing Women, Australian Journal of Management, 43 (1), 132-151.

İmamoğlu Akman, G. ve Akman, Y. (2016). Kraliçe Arı Sendromu Bağlamında Kadın Öğretmenlerin Kadın Yöneticilere İlişkin Görüşleri, Bartın Üniversitesi Ĕ̆itim Fakültesi Dergisi, 5 (3), 748-763.

Jackson, J. F. L. ve O'Callaghan, E. M. (2009). What Do We Know About Glass Ceiling Effects? A Taxonomy and Critical Review to Inform Higher Education Research, Research in Higher Education, 50, 460-482.

Kadın Çalışan Erkek Yönetici Tercih Ediyor. https://www.kigem.com/kadin-calisan-erkek-yonetici-tercihediyor.html (Erişim Tarihi: 19 Şubat 2020).

Kanter, R. M. (1993). Men and Women of the Corporation, New York, Basic Books.

Karaca, A. (2007). Kadın Yöneticilerde Kariyer Engelleri: Cam Tavan Sendromu Üzerine Uygulamah Bir Araştırma. Selçuk Üniversitesi SBE, Yüksek Lisans Tezi. Konya

Karakuş, H. (2014). Kraliçe Arı Sendromu - Pembe Taciz, Akademik Sosyal Araştırmalar Dergisi, 2 (1), 334-356.

Kızıldağ, D. (2018). Yönetimde Kadın Sorunsalı. Yönetim Araştırmaları Dergisi, 14 (1-2), 48-69.

Kurt Yılmaz, B. (2019). Cinsiyete Dayalı Tokenizm: Kadın Egemen ve Erkek Egemen Mesleklerde Nitel Bir Araştırma. Dokuz Eylül Üniversitesi SBE, Doktora Tezi, İzmir.

Mukhtar, S. M. (2002). Differences in Male and Female Management Characteristics: A Study of OwnerManager Businesses, Small Business Economics, 18 (4), 289-311.

Negiz, N. ve Yemen, A. (2011). Kamu Örgütlerinde Kadın Yöneticiler: Yönetici ve Çalışan Açısından Yönetimde Kadın Sorunsalı, Süleyman Demirel Üniversitesi Fen Edebiyat Fakültesi Sosyal Bilimler Dergisi, 24, 195-214.

Özen, Ş. (1998). Türkiye'de Kadın ve Erkek Kamu Yöneticilerinin Yönetim Tarzı Açısından Farklılaşması ve Eril Erkek - Dişil Kadın Varsayımının Geçerliliği. 20. Yüzyılın Sonunda Kadınlar ve Gelecek Konferansı. 
E. Tolay $12 / 3(2020) 2276-2296$

Ankara, Türkiye ve Orta Doğu Amme İdaresi Enstitüsü, İnsan Hakları Araştırma ve Derleme Merkezi Yayin No: 16., 217-236.

Powell, G. N. (1990). One More Time: Do Female and Male Managers Differ?, Academy of Management, 4 (3), 68-75.

Randstad Araştırması. (2016). https://www.randstad.com.tr/hakkimizda/haberler-ve-duyurular/randstadtanhaberler/erkek-calisanlar-yoneticilik-pozisyonlari-icin-desteklenirken-calisanlar-cinsiyet-esitligiolan-takimlarda-calismayi-tercih-ediyorlar (Erişim Tarihi: 1 Mart 2020).

Schein, V. E. (1975). Relationships Between Sex Role Stereotypes and Requisite Management Characteristics among Female Managers, Journal of Applied Psychology, 60 (3), 340-344.

Schein, V. (2007). Women in Management: Reflections and Projections. Women in Management Review, 22 (1), 6-18.

Sertkaya, Ö., Onay, M. ve Ekmekçi, R. (2013). Spor Örgütlerinde Kadın Yöneticilere Yönelik Tutumların Belirlenmesi, Pamukkale Journal of Sport Sciences, 4 (Special Issue), 1-13.

Statham, A. (1987). The Gender Model Revisited: Differences in the Management Styles of Men and Women, Sex Roles, 16, 409-430.

Stoker, J. I., Van der Velde, M. ve Lammers, J. (2012). Factors Relating to Managerial Stereotypes: The Role of Gender of the Emlpoyee and the Manager and Management Gender Ratio, Journal of Business and Psychology, 27 (1), 31-42.

Sundaresan, S. (2010). Are Women Managers Different from Men Managers? Journal of Women's Studies, 2, https://www.researchgate.net/publication/273004183 (Erişim Tarihi: 28 Mart 2020).

Tekyazman, E. F. (2019). Spor Eğitimi Veren Yükseköğretim Kurumlarında Kraliçe Arı Sendromu. Celal Bayar Üniversitesi SBE, Yüksek Lisans Tezi, Manisa.

Tolay, E. (2020). Paternalist Liderlik Beklentisi: Y Kuşağı İşletme Öğrencileri Üzerine Bir Araştırma, İzmir Iktisat Dergisi, 35 (1), 123-139.

Uçan, M. (2012). İlköğretim Okullarında Görev Yapan Öğretmenlerin Kadın Yöneticilere Yönelik Tutumlarn ile Kadın Yöneticilerde Algıladıkları Liderlik Stilleri Arasındaki İlişki (İstanbul İli Kadıköy İlçesi Örneği), Yeditepe Üniversitesi SBE, Yüksek Lisans Tezi, İstanbul.

Ustabaş, A. ve Afacan Fındıklı, M. (2017). Çalışma Hayatında Kadın Yönetici Olmak: Türkiye'de Sanayi Sektöründe Kadın yöneticilerin Karşılaştıkları Sorunlar, KSBD, 9 (9), 421-441.

Willemsen, T. M. (2002). Gender Typing of the Succesfull Manager - A Stereotype Reconsidered, Sex Roles, 46, 385-391.

Yıldırım, A. ve Şimşek, H. (2013). Sosyal Bilimlerde Nitel Araştırma Yöntemleri, Ankara, Seçkin Yayınevi. 